\title{
Pediatric Catecholaminergic Polymorphic Ventricular Tachycardia: A Translational Perspective for the Clinician-Scientist
}

\author{
Dania Kallas 1,+(D), Avani Lamba ${ }^{1,+}$, Thomas M. Roston ${ }^{1,2}$, Alia Arslanova ${ }^{3,4}$, Sonia Franciosi ${ }^{1}$, Glen F. Tibbits ${ }^{3,4}$ \\ and Shubhayan Sanatani ${ }^{1, *}$
}

1 British Columbia Children's Hospital Heart Center, 1F9-4480 Oak St., Vancouver, BC V6H 3V4, Canada; dania.kallas@bcchr.ca (D.K.); avani.lamba@bcchr.ca (A.L.); rostontm@alumni.ubc.ca (T.M.R.); sonia.franciosi@cw.bc.ca (S.F.)

2 Clinician-Investigator Program, University of British Columbia, 2016-1874 East Mall, Vancouver, BC V6T 1Z1, Canada

3 Cellular and Regenerative Medicine Centre, British Columbia Children's Hospital Research Institute, 938 W 28th Ave, Vancouver, BC V5Z 4H4, Canada; arslanov@sfu.ca (A.A.); tibbits@sfu.ca (G.F.T.)

4 Molecular Cardiac Physiology Group, Department of Biomedical Physiology and Kinesiology, Simon Fraser University, 8888 University Dr., Burnaby, BC V5A 1S6, Canada

* Correspondence: ssanatani@cw.bc.ca

+ These authors contributed equally to this work.

check for updates

Citation: Kallas, D.; Lamba, A.; Roston, T.M.; Arslanova, A.; Franciosi, S.; Tibbits, G.F.; Sanatani, S. Pediatric Catecholaminergic Polymorphic Ventricular Tachycardia: A Translational Perspective for the Clinician-Scientist. Int. J. Mol. Sci. 2021, 22, 9293. https://doi.org/ $10.3390 /$ ijms 22179293

Academic Editor: Francesco Moccia

Received: 27 July 2021

Accepted: 24 August 2021

Published: 27 August 2021

Publisher's Note: MDPI stays neutral with regard to jurisdictional claims in published maps and institutional affiliations.

Copyright: (c) 2021 by the authors. Licensee MDPI, Basel, Switzerland. This article is an open access article distributed under the terms and conditions of the Creative Commons Attribution (CC BY) license (https:// creativecommons.org/licenses/by/ $4.0 /)$.

\begin{abstract}
Catecholaminergic polymorphic ventricular tachycardia (CPVT) is a rare and potentially lethal inherited arrhythmia disease characterized by exercise or emotion-induced bidirectional or polymorphic ventricular tachyarrhythmias. The median age of disease onset is reported to be approximately 10 years of age. The majority of CPVT patients have pathogenic variants in the gene encoding the cardiac ryanodine receptor, or calsequestrin 2 . These lead to mishandling of calcium in cardiomyocytes resulting in after-depolarizations, and ventricular arrhythmias. Disease severity is particularly pronounced in younger individuals who usually present with cardiac arrest and arrhythmic syncope. Risk stratification is imprecise and long-term prognosis on therapy is unknown despite decades of research focused on pediatric CPVT populations. The purpose of this review is to summarize contemporary data on pediatric CPVT, highlight knowledge gaps and present future research directions for the clinician-scientist to address.
\end{abstract}

Keywords: ventricular tachycardia; sudden cardiac death; pediatric electrophysiology; catecholaminergic polymorphic ventricular tachycardia; inherited arrhythmia; primary electrical disease; ryanodine receptor

\section{Introduction}

Catecholaminergic polymorphic ventricular tachycardia (CPVT) is a rare and potentially lethal cardiac ion channelopathy associated with a normal resting electrocardiogram (ECG) and normal cardiac structure and function [1-4]. CPVT is characterized by exercise or emotion-mediated polymorphic or bidirectional ventricular tachycardia (VT), which may lead to syncope and sudden cardiac death (SCD) [5]. The prevalence of CPVT is reported to be 1:10,000 [6], however, this is an estimate lacking validation. CPVT is most associated with autosomal dominant gain-of-function variants in the $R Y R 2$-encoded cardiac ryanodine receptor-2 (RyR2) and recessive variants in CASQ2-encoded calsequestrin-2 (CASQ2), both of which affect intracellular $\mathrm{Ca}^{2+}$ (calcium) handling properties upon adrenergic stimulation and have a potential to trigger delayed after-depolarizations (DADs) and arrhythmias [7,8].

B-blockers are the first line therapy, though breakthrough cardiac events often occur despite drug adherence [9-11]. A previous study reported that around $25 \%$ of children 
experienced syncope or cardiac arrest despite $\beta$-blocker treatment [12]. In patients with recurrent arrhythmias despite ß-blockers, flecainide should be added [13-16]. Implantable cardioverter defibrillators (ICDs) are indicated for CPVT patients who have suffered cardiac arrest or have recurrent life-threatening VTs on maximal medical therapy [6]. However, ICDs have been associated with high rates of inappropriate shocks and complications, probably due to catecholamine release after an initial painful shock [17]. Left cardiac sympathetic denervation (LCSD) is another therapeutic strategy for refractory CPVT, including those with ICDs in situ [18].

Data about individual prognosis remains difficult to determine due to the broad spectrum of CPVT phenotypes described in previous reports. As many as 30\% of CPVT patients have been reported to experience sudden unexpected death (SUD) by the age of 30 years [1]. Patients who are first to receive a diagnosis in their family (index case or proband) often have more severe phenotypes and are at greater risk of cardiac events $[19,20]$. In addition, children with CPVT typically present with more severe phenotypes compared to adults and are more vulnerable to the occurrence of sudden death [9]. This review will address pediatric CPVT specifically, by discussing genotypic advances, pathophysiology, clinical presentation, diagnoses and contemporary therapeutic options in this cohort.

\section{History of CPVT}

CPVT was likely first described over 60 years ago by Berg [21] (Figure 1) and subsequently by Reid et al. in 1975 [22]. These reports described childhood-onset emotion and exertion induced ventricular extrasystoles in the absence of structural heart abnormalities. Reid et al. recognized that CPVT was probably familial in nature. The first longitudinal study describing CPVT as a distinct inherited cardiac disease was published in 1995 by Leenhardt et al. [1]. The genetic basis of CPVT was reported in 2001, with autosomal dominant variants in $R Y R 2[7,23]$ and recessive variants $C A S Q 2$ identified as causes of the disease [8].

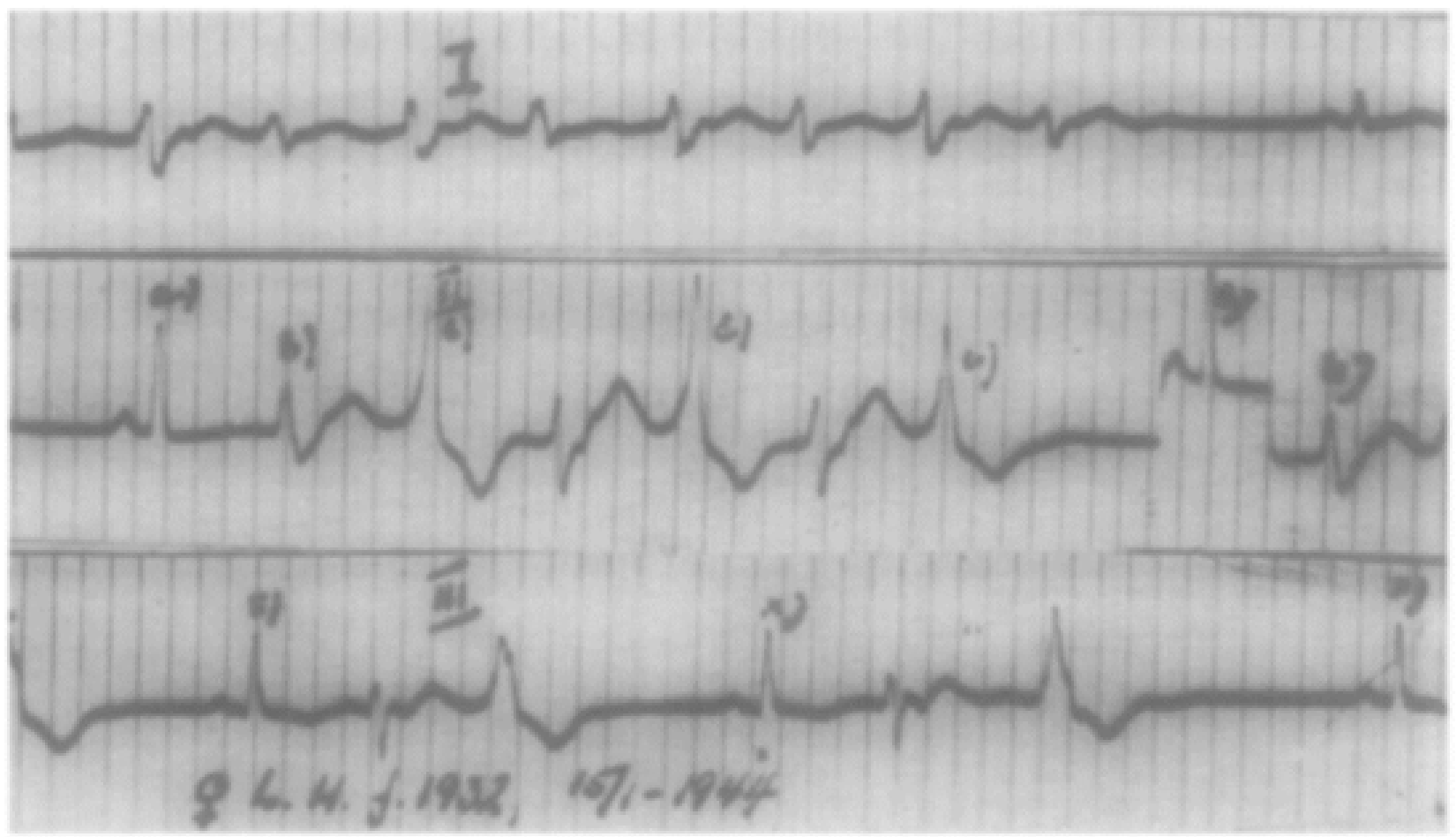

Figure 1. Historic electrocardiogram recording showing frequent ventricular extrasystole in 1944. Image obtained with permission from: Berg, K. J. (1960). Multifocal ventricular extrasytoles with Adams-Stokes syndrome in siblings. American Heart Journal, 60(6), 965-970. 


\section{Genetics}

\subsection{Ryanodine Receptor 2}

A CPVT phenotype was first mapped to a locus on chromosome 1q42-q43 (Table 1) [2]. Subsequent studies identified missense variants in the sarcoplasmic reticulum (SR) $\mathrm{Ca}^{2+}$ release channel gene, $R Y R 2$, mapped on this disease locus [7,23]. RyR2, a large tetrameric ion channel, is involved in excitation-contraction (E-C) coupling in cardiac myocytes and plays an important role in $\mathrm{Ca}^{2+}$ homeostasis within the cardiac tissue [24]. Gain of function (GOF) variants in RYR2 are associated with an autosomal dominant form of CPVT [7], and are attributed to $60 \%$ of cases [7].

Table 1. Genetic subtypes of CPVT.

\begin{tabular}{|c|c|c|c|c|c|c|}
\hline $\begin{array}{l}\text { CPVT } \\
\text { Subtype }\end{array}$ & Gene & $\begin{array}{l}\text { Protein } \\
\text { Name }\end{array}$ & $\begin{array}{l}\text { Chromosome } \\
\text { Locus }\end{array}$ & $\begin{array}{l}\text { Inheritance } \\
\text { Pattern }\end{array}$ & $\begin{array}{l}\text { Proportion of Cases } \\
\text { Associated with This Gene }\end{array}$ & $\begin{array}{c}\text { Year } \\
\text { Discovered }\end{array}$ \\
\hline CPVT1 & $R Y R 2$ & $\begin{array}{l}\text { Ryanodine } \\
\text { Receptor } 2\end{array}$ & $1 q 43$ & $\begin{array}{l}\text { Autosomal } \\
\text { Dominant }\end{array}$ & $55-60 \%$ [7] & 2001 \\
\hline CPVT2 & CASQ2 & $\begin{array}{l}\text { Calsequestrin } \\
2\end{array}$ & 1p13.1 & $\begin{array}{c}\text { Autosomal } \\
\text { Recessive/ } \\
\text { Autosomal } \\
\text { Dominant [25] }\end{array}$ & $2-5 \%[8]$ & 2001 \\
\hline CPVT3 * & TECRL & $\begin{array}{c}\text { Trans-2,3- } \\
\text { enoyl-CoA } \\
\text { reductase-like }\end{array}$ & 7p22-p14 & $\begin{array}{l}\text { Autosomal } \\
\text { Recessive }\end{array}$ & $<1 \%[26]$ & 2016 \\
\hline CPVT4* & CALM1 & Calmodulin & $14 q 32.11$ & $\begin{array}{l}\text { Autosomal } \\
\text { Dominant }\end{array}$ & $<1 \%$ [27] & 2012 \\
\hline CPVT5 * & $T R D N$ & Triadin & $6 \mathrm{q} 22.31$ & $\begin{array}{l}\text { Autosomal } \\
\text { Recessive }\end{array}$ & $1-2 \%[28]$ & 2012 \\
\hline
\end{tabular}

* Usually with other distinctive evidence of a competing inherited arrhythmia syndrome phenotype.

\subsection{Calsequestrin 2}

In 2001, Lahat et al. found missense variants in highly conserved regions of another gene involved in the regulation of $\mathrm{Ca}^{2+}$ homeostasis of the heart, CASQ2, causing an autosomal recessive form of CPVT in seven Bedouin families [8]. CASQ2 has historically been associated with an autosomal recessive form of CPVT, however autosomal dominant inheritance has also been described in isolated studies and further confirmed in a recent international multi-centre study on CASQ2 inheritance patterns $[25,29,30]$. Approximately $2-5 \%$ of $C P V T$ cases are attributed to $C A S Q 2$ variants. However, given that heterozygote $C A S Q 2$ patients may also have a CPVT phenotype, the true prevalence of CASQ2 associated CPVT is debatable [25]. Pathogenic variants in the RYR2 and CASQ2 genes underlie CPVT1 and CPVT2, respectively, with CPVT2 patients typically presenting at a younger age $[8,25,31]$.

\subsection{Trans-2,3-enoyl-CoA Reductase-like}

Several additional genes have been linked to CPVT. A CPVT phenotype associated with an autosomal recessive mode of inheritance, mapped to chromosome locus 7p22-p14, was first described in a consanguineous Arabic family by Bhuiyan et al. in 2007 [32]. This disease form was recently attributed to gene variants in trans-2,3-enoyl-CoA reductaselike (TECRL) encoding a protein expressed in the endoplasmic reticulum of myocardial cells, belonging to the steroid 5-alpha reductase family. Patients with variants in TECRL comprise $<1 \%$ of CPVT cases and the molecular mechanism of disease in these patients is unestablished. This is a highly lethal form of CPVT, with patients first presenting symptoms during childhood, with a recent multicentre study reporting a median age of symptom onset at 8 years of age [33]. 


\subsection{Calmodulin and Triadin}

Variants in CALM1-encoded calmodulin, a $\mathrm{Ca}^{2+}$ binding protein, and TRDN-encoded Triadin, a cardiac $\mathrm{Ca}^{2+}$ release complex protein, have also been implicated in atypical CPVT and are associated with $1-2 \%$ of CPVT cases $[27,28]$. Phenotypes associated with these genes are more complex and variable than classic CPVT. Other mimickers of CPVT also exist. A minority of patients $(<1 \%)$ with phenotypic features of CPVT have also been found to be heterozygous for ANK2, SCN5A, or KCNJ2 variants [34-37]. None of these genes cause CPVT in isolation, and instead lead to complex overlapping forms of long QT syndrome (LQTS) and ventricular ectopy [38,39].

\subsection{Expressivity and Penetrance}

It is increasingly recognized that CPVT associated genetic variants can result in incomplete penetrance and variable expressivity. Various studies have described marked phenotypic diversity amongst young relatives carrying $R Y R 2$ variants diagnosed through cascade screening. [5] [19,40]. Variable expressivity of the CPVT phenotype could possibly be explained by polygenic influences that cause certain CPVT patients to be more susceptible to life-threatening arrhythmic events. In other autosomal dominant inherited cardiac diseases, like hypertrophic cardiomyopathy, Brugada syndrome and LQTS, genetic modifier research is more mature [41-44]. Conversely, no modifiers have been identified in CPVT to date [19,45]. A minority of pediatric CPVT patients remain genetically elusive [31] making gene discovery in this subset of patients necessary. Genome wide association studies (GWAS) may be a beneficial next step in identifying disease susceptibility variants. A recent transethnic GWAS study in LQTS utilized polygenic score analyses and demonstrated polygenic influence in expression of phenotype in genotype negative patients [46].

\section{Pathophysiology}

\subsection{Mechanisms of Intracellular $\mathrm{Ca}^{2+}$ Regulation}

CPVT-associated genes encode proteins vital to the regulation of $\mathrm{Ca}^{2+}$ in cardiomyocytes. During the cardiac E-C coupling, a wave of depolarization originating from the influx of $\mathrm{Na}^{+}$(sodium) through the $\mathrm{Na}^{+}$channels $\left(\mathrm{Na}_{V 1.5}\right)$, traverses through the sarcolemma and reaches the t-tubules, which causes opening of the L-type $\mathrm{Ca}^{2+}$ channels ( $\mathrm{Cav1}_{12}$ and also known as dihydropyridine receptors). This facilitates subsequent influx of $\mathrm{Ca}^{2+}$ into the cytosol. An increase in cytosolic $\mathrm{Ca}^{2+}$ triggers $\mathrm{Ca}^{2+}$ release from the SR (the $\mathrm{Ca}^{2+}$ storage unit of the cardiac myocyte) through a process known as $\mathrm{Ca}^{2+}$-induced $\mathrm{Ca}^{2+}$ release (CICR) as a result of RyR2 activation by cytosolic $\mathrm{Ca}^{2+}$ (Figure 2) [47]. RyR2 $\mathrm{Ca}^{2+}$ release is facilitated by CASQ2 $\left(\mathrm{a} \mathrm{Ca}^{2+}\right.$ buffering protein within the SR regulating the levels of free $\mathrm{Ca}^{2+}$ in the SR), triadin and junctin (both mediate the interaction between $\mathrm{Ca}^{2+}$ handling proteins, CASQ2 and RyR2) forming the SR Ca ${ }^{2+}$ release complex. Together, they also confer RyR2 responsiveness to luminal $\mathrm{Ca}^{2+}[48]$. 


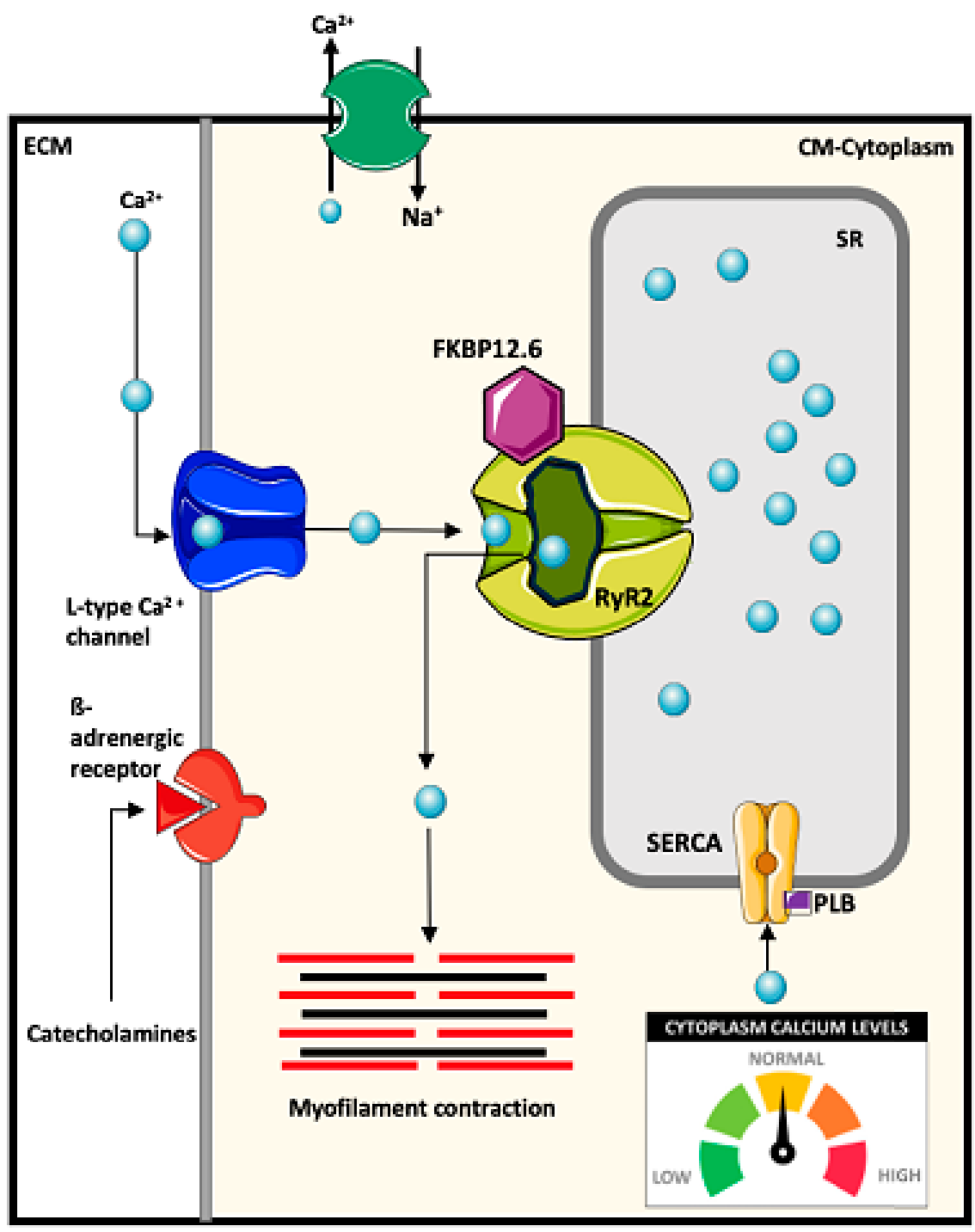

Figure 2. $\mathrm{Ca}^{2+}$ induced $\mathrm{Ca}^{2+}$ release mechanism: The cardiac action potential leads to membrane depolarization, thereby opening L-type $\mathrm{Ca}^{2+}$ channels $\left(\mathrm{Ca}_{\mathrm{V} 1.2}\right) . \mathrm{Ca}^{2+}$ in the cytosol then binds to the ryanodine receptor 2 (RyR2) leading to CICR from the sarcoplasmic reticulum (SR) lumen into the cytosol. During systole, the cytosolic $\mathrm{Ca}^{2+}$ then binds to troponin $\mathrm{C}$ which leads to myocardial contraction. $\mathrm{Ca}^{2+}$ in the cytoplasm is returned to the $\mathrm{SR}$ via the sarco/endoplasmic reticulum $\mathrm{Ca}^{2+}$-ATPase (SERCA2a) and its regulatory protein phospholamban (PLB). CM = cardiomyocyte; $\mathrm{ECM}=$ extracellular matrix. Image adapted from Priori, S. G., and Chen, S. W. (2011), Circulation Research, 108(7), 871-883 [49].

During systole, the cytosolic $\mathrm{Ca}^{2+}$ then binds to troponin $\mathrm{C}$ of the troponin complex facilitating myocardial contraction [50,51]. E-C coupling can also be influenced by sympathetic nervous system (i.e., exercise or stress) which promotes catecholamine release and subsequent activation of protein kinase A (PKA)-mediated pathway as a result of $\mathrm{B}_{1}$-adrenergic stimulation. PKA is capable of phosphorylating several key regulatory and accessory proteins modulating cardiac contractility through regulation of intracellular $\mathrm{Ca}^{2+}$ [52]. These target proteins include: (1) L-type $\mathrm{Ca}^{2+}$ channels, increasing $\mathrm{Ca}^{2+}$ influx and eventually CICR from the SR [53]; (2) RyR2, enhancing SR Ca ${ }^{2+}$ release; (3) phospholamban (PLB), promoting $\mathrm{Ca}^{2+}$ reuptake back into the $\mathrm{SR}$ through disinhibition of sarco/endoplasmic reticulum $\mathrm{Ca}^{2+}$-ATPase (SERCA2a) [53,54]; or (4) troponin I and myosin-binding protein $\mathrm{C}$, improving myofilament $\mathrm{Ca}^{2+}$ sensitivity, myocardial relaxation rate and force generation $[53,55,56]$. During diastole, myocardial relaxation is induced by 
cycling the cytosolic $\mathrm{Ca}^{2+}$ through two primary mechanisms involving SERCA2a which pumps $\mathrm{Ca}^{2+}$ back into SR and the $\mathrm{Na}^{+} / \mathrm{Ca}^{2+}$ exchanger (NCX) which extrudes $\mathrm{Ca}^{2+}$ out of the cell $[57,58]$.

In addition to CICR-mediated SR Ca ${ }^{2+}$ release, the spontaneous release of $\mathrm{Ca}^{2+}$ from the SR can also be caused by store overload-induced $\mathrm{Ca}^{2+}$ release (SOICR) which can trigger $\mathrm{Ca}^{2+}$ oscillations [49]. Disruption in intracellular $\mathrm{Ca}^{2+}$ handling affecting these $\mathrm{Ca}^{2+}$ release pathways can facilitate the onset of DADs. If the membrane depolarization produced by DADs is large enough, it can lead to repeated premature and uncoordinated activation of cardiac tissue $[50,51]$.

\subsection{Ryanodine Receptor-2 Associated Arrhythmogenesis}

Gain of function variants in $R Y R 2$ lead to altered functional properties making the channel prone to spontaneous diastolic SR $\mathrm{Ca}^{2+}$ leak. This effect is further exacerbated during the episodes of sympathetic activation (i.e., exercise, stress) due to phosphorylation of several key $\mathrm{Ca}^{2+}$ handling proteins mediated by the $\beta_{1}$-adrenergic pathway. The resulting aberrant SR $\mathrm{Ca}^{2+}$ release causes a local rise in $\mathrm{Ca}^{2+}$ which activates NCX to drive $\mathrm{Ca}^{2+}$ extrusion in exchange for $\mathrm{Na}^{+}$influx. This generates a transient inward current that promotes the onset of DADs, which if large enough to reach a threshold for $\mathrm{Na}^{+}$channel activation, can subsequently initiate action potentials and the onset of VT $[49,59]$.

Despite the commonality in the mechanism that leads to DADs underlying CPVT arrhythmogenesis, several hypotheses, likely influenced by the location of the $R Y R 2$ variants and their effect on structure, gating, and regulation of the channel, have been outlined to converge to this conclusion (Figure 3) [60,61]. A hypothesis that has been well documented by Chen and colleagues suggests that $R Y R 2$ variants enhance channel's sensitivity to the luminal $\mathrm{Ca}^{2+}$ concentration reducing the threshold for spontaneous $\mathrm{SR} \mathrm{Ca}^{2+}$ through a SOICR-mediated mechanism (Figure 3A) [49,62-64]. Reduced SOICR threshold promotes activation of RyR2 at lower SR $\mathrm{Ca}^{2+}$ amounts increasing susceptibility to triggered DADs, and these effects are even further exacerbated during $\beta$-adrenergic stimulation [49]. A second hypothesis underlying $R Y R 2$-dependent CPVT proposes that $R Y R 2$ variants cause an impaired binding affinity of the FKBP12.6, a protein involved in stabilizing a closed state of the RyR2 channel during diastole, to the RyR2 monomers (Figure 3B) [65]. This particularly impacts RyR2 function during PKA-mediated phosphorylation which causes further dissociation of FKBP12.6 from RyR2 increasing its open probability state which, thereby, promotes diastolic SR $\mathrm{Ca}^{2+}$ leak [65]. This mechanism has been challenged by Xiao et al., who found that loss of FKBP12.6 has no effect on conduction or activation of RyR2, nor does it affect the susceptibility to stress-induced ventricular arrythmias [66]. A third hypothesis proposes that impaired RyR2 interdomain interaction between the $\mathrm{N}$-terminal and central domains, as a result of $R Y R 2$ variants, result in folding abnormalities that destabilize the functional behavior of the channel (Figure 3C) [67]. Normally, the domains interact to form a tight intramolecular structure, "zipping" the channel in a closed conformation and stabilizing it [68]. RYR2 variants affecting these domains have the ability to weaken intramolecular interactions of the $\mathrm{N}$-terminal/central domain pair which contributes to $\mathrm{Ca}^{2+}$ leak through RyR2 and initiation of DADs [63,68-71]. 

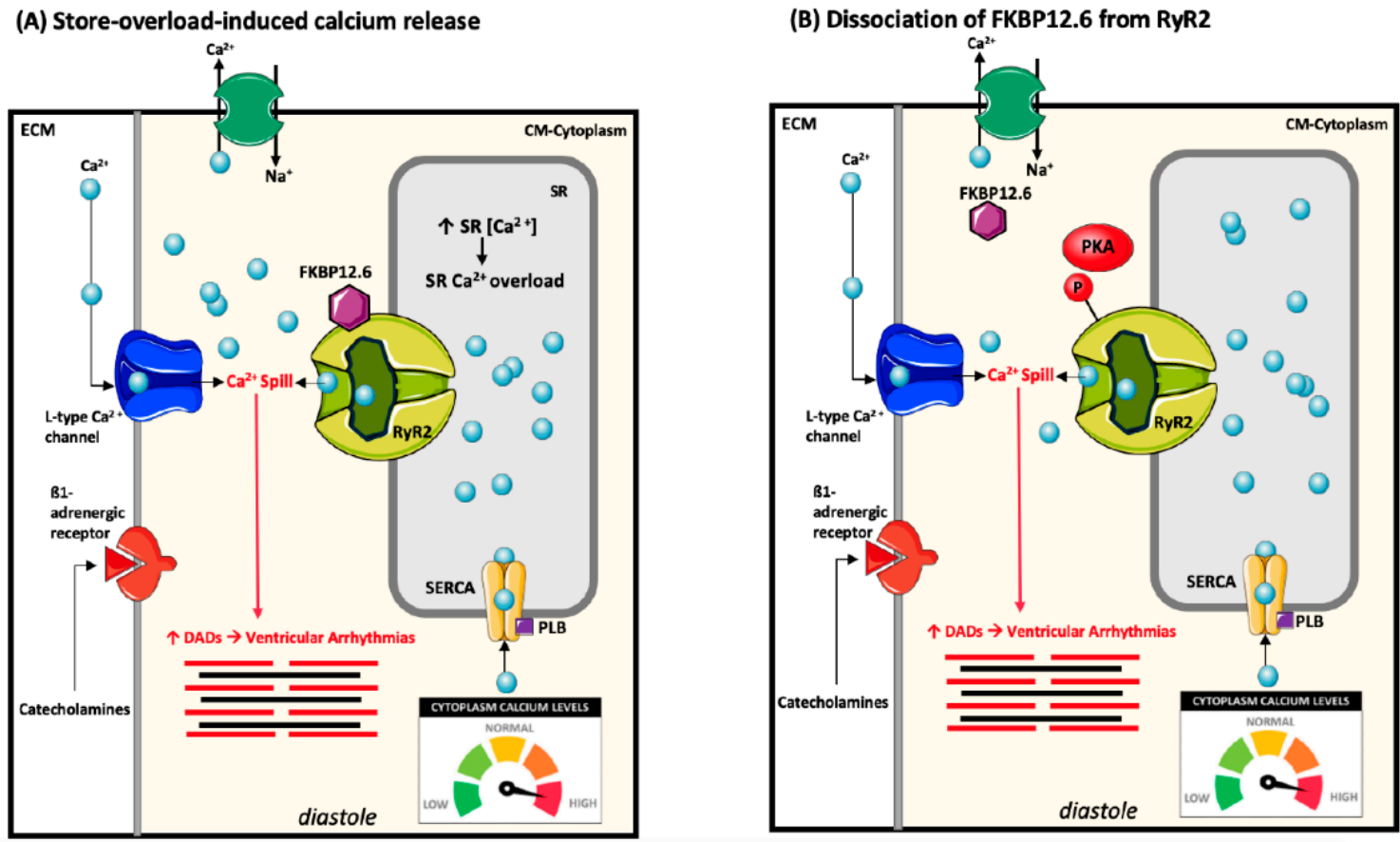

C) Unzipping of RyR2 N-terminal and central domain

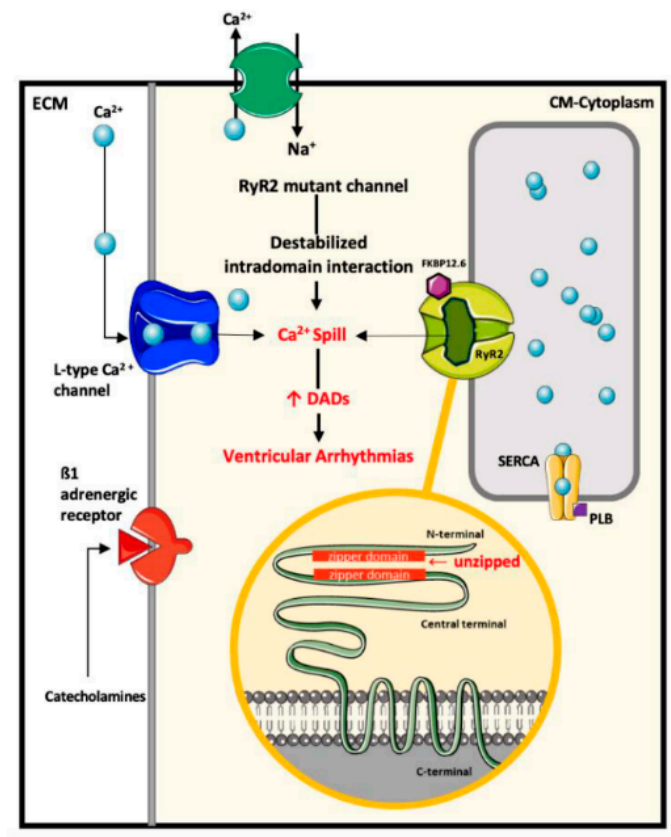

Figure 3. Proposed mechanisms of $R Y R 2$-associated CPVT arrhythmogenesis: (A) Store overload-induced Ca ${ }^{2+}$ release: RyR2 mutant channels may exhibit an increased sensitivity to the luminal $\mathrm{Ca}^{2+}$ in the SR by decreasing the threshold needed to activate it, leading to increased $\mathrm{Ca}^{2+}$ release from the SR during diastole. This leads to delayed afterdepolarizations (DADs) and thus, uncoordinated activation of cardiac tissue and triggered ventricular arrhythmias. (B) FKBP12.6 dissociation from the RyR2-complex: FKBP12.6 is phosphorylated by protein kinase A, leading to its dissociation from mutant RyR2, increasing diastolic $\mathrm{Ca}^{2+}$ release and consequent contractility. (C) Unzipping of the N-terminal and central terminal of the RyR2 protein: N-terminal and the central domain of wildtype RyR2 interact to form a tight intramolecular structure or a "zip" to stabilize the channel. However, RyR2 mutant channels cause weak intramolecular domain interaction resulting in $\mathrm{Ca}^{2+}$ spill. $\mathrm{P}=$ phosphate group; Other abbreviations as indicated in Figure 2. Image adapted from Wleklinski, M. J., Kannankeril, P. J., and Knollmann, B. C. (2020). The Journal of Physiology, 598(14), 2817-2834 [60]. 


\subsection{Calsequestrin-2 Associated Arrhythmogenesis}

CASQ2 is a high capacity and low affinity $\mathrm{Ca}^{2+}$ binding protein. It forms dynamic $\mathrm{Ca}^{2+}$-dependent linear polymers through the binding of $\mathrm{Ca}^{2+}$ in electronegative pockets within CASQ2 dimers, leading to dimer cross bridging [72,73]. Variants in CASQ2 leads to a reduction in this protein's $\mathrm{Ca}^{2+}$ binding capacity [72]. CASQ2 variants can lead to various protein structural abnormalities, ranging from CASQ2 monomers that are unable to dimerize to disrupted hydrophobic cores in protein domains resulting in formation of $\mathrm{Ca}^{2+}$ desensitized high molecular aggregates [72]. A recent study on pathogenic heterozygous CASQ2 variants showed that mutant proteins displayed filamentation defects, with one variant failing to dimerize.

\subsection{TRDN, CALM1, and TECRL Associated Arrhythmogenesis}

Pathogenic variants in TRDN, CALM1, and TECRL are rare causes of CPVT3, CPVT4, and CPVT5, respectively. Autosomal recessive TRDN variants were found to be associated with intracellular retention and protein degradation of mutant Triadin both in cell culture and mouse models [28]. Dominantly inherited CALM variants have been shown to cause $\mathrm{Ca}^{2+}$ binding defects as well as disrupted RyR2-Calmodulin protein interactions [27]. TECRL has been shown to play a role in intracellular $\mathrm{Ca}^{2+}$ homeostasis, with mutant human induced pluripotent stem cell-derived cardiomyocytes (hiPSC-CMs) showing elevated diastolic $\mathrm{Ca}^{2+}$ levels, decreased SERCA and NCX activities, and prolonged action potentials compared to control hiPSC-CMs [74].

\section{Clinical Presentation}

Most CPVT patients experience cardiac events during exercise or emotional stress. Cohort studies of pediatric CPVT patients are presented in Table 2. Life-threatening cardiac events during wakeful and normal daily activities have also been reported, possibly due to anxiety, stress, or other non-exertional psychological stimuli [31]. Patients typically present with palpitations, syncope, arrhythmia-induced seizures, resuscitated cardiac arrest, or SCD. Symptoms in CPVT are usually due to polymorphic VT, bidirectional VT, or ventricular fibrillation (VF), but may also be caused by atrial arrhythmias [75]. Sy et al. reported a bimodal age distribution in CPVT onset, with a third of patients presenting before the age of 21 [11]. They also found that patients presenting at an older age were less likely to have an $R Y R 2$ variant [11]. By age 10, about $35 \%$ of patients are symptomatic, and this rises to $72 \%$ by 21 years of age, indicating that CPVT is a predominantly pediatric-onset condition [9]. SCD in a relative $<40$ years of age has been reported in $74 \%$ of asymptomatic children evaluated as part of family screening [12].

Table 2. Cohort studies of pediatric CPVT patients.

\begin{tabular}{|c|c|c|c|c|c|c|}
\hline \multirow[b]{2}{*}{ Author } & \multirow{2}{*}{$\begin{array}{c}\text { Year } \\
\text { Published }\end{array}$} & \multicolumn{2}{|c|}{ CPVT Cases (n) } & \multirow{2}{*}{$\begin{array}{c}\text { Mean/Median Age of } \\
\text { Symptom-Onset } \\
\text { (Years) }\end{array}$} & \multirow{2}{*}{$\begin{array}{l}\text { Cardiac Events at } \\
\text { Follow-Up }\end{array}$} & \multirow[b]{2}{*}{ Conclusions/Significance } \\
\hline & & Proband & $\begin{array}{l}\text { Family } \\
\text { Member }\end{array}$ & & & \\
\hline $\begin{array}{l}\text { Leenhardt } \\
\text { et al. [1] }\end{array}$ & 1995 & 20 & 1 & $7.8 \pm 4.0$ & $\begin{array}{l}2 \mathrm{SCD} \text { over a } \\
\text { mean of } 7 \text { years }\end{array}$ & $\begin{array}{l}\text { First large description of } \\
\text { CPVT as } \\
\text { adrenergic-induced lethal } \\
\text { tachyarrhythmias in the } \\
\text { absence of structural heart } \\
\text { disease }\end{array}$ \\
\hline $\begin{array}{l}\text { Swan et al. } \\
\text { [2] }\end{array}$ & 1999 & 14 (in & ilies) & $21 \pm 10$ & $\begin{array}{l}1 \text { patient with } \\
\text { syncope and } \\
\text { cardiac arrest } \\
\text { over } 8 \pm 6 \text { years }\end{array}$ & $\begin{array}{l}\text { Arrhythmia disease mapped } \\
\text { to chromosome 1q42-q43. }\end{array}$ \\
\hline $\begin{array}{l}\text { Lahat et al. } \\
\quad[8]\end{array}$ & 2001 & 13 (in & ilies) & $6 \pm 3$ & $\begin{array}{l}1 \text { SCD over } 40 \\
\text { months }\end{array}$ & $\begin{array}{c}\text { First CASQ2-associated } \\
\text { autosomal recessive CPVT } \\
\text { case reported. }\end{array}$ \\
\hline
\end{tabular}


Table 2. Cont.

\begin{tabular}{|c|c|c|c|c|c|c|}
\hline \multirow[b]{2}{*}{ Author } & \multirow{2}{*}{$\begin{array}{c}\text { Year } \\
\text { Published }\end{array}$} & \multicolumn{2}{|c|}{ CPVT Cases (n) } & \multirow{2}{*}{$\begin{array}{c}\text { Mean/Median Age of } \\
\text { Symptom-Onset } \\
\text { (Years) }\end{array}$} & \multirow{2}{*}{$\begin{array}{c}\text { Cardiac Events at } \\
\text { Follow-Up }\end{array}$} & \multirow[b]{2}{*}{ Conclusions/Significance } \\
\hline & & Proband & $\begin{array}{l}\text { Family } \\
\text { Member }\end{array}$ & & & \\
\hline $\begin{array}{c}\text { Bauce et al. } \\
\text { [4] }\end{array}$ & 2002 & \multicolumn{2}{|c|}{43 (in 8 families) } & Not reported & $\begin{array}{l}\text { No events during } \\
\text { follow-up }\end{array}$ & $\begin{array}{c}\text { Genetic screening is } \\
\text { important for early } \\
\text { diagnosis of asymptomatic } \\
\text { carriers. }\end{array}$ \\
\hline $\begin{array}{c}\text { Priori et al. } \\
\text { [3] }\end{array}$ & 2002 & 30 & 9 & $\begin{array}{c}8 \pm 2, R Y R 2 \text {-associated } \\
\text { cases; } 20 \pm 12 \\
\text { Non-genotyped cases }\end{array}$ & Not reported & $\begin{array}{l}\text { Non-genotyped CPVT cases } \\
\text { are often women with } \\
\text { late-onset of symptoms. } \\
\text { RYR2-associated CPVT } \\
\text { often have an early-onset of } \\
\text { symptoms. Men are at } \\
\text { higher risk of cardiac events. }\end{array}$ \\
\hline $\begin{array}{l}\text { Sumitomo } \\
\text { et al. [10] }\end{array}$ & 2003 & 25 & 4 & $10.3 \pm 6.1$ & $\begin{array}{c}7(25 \%) \text { SCD over } \\
\text { mean } 6.8 \pm 4.9 \\
\text { years }\end{array}$ & Prognosis is poor. \\
\hline $\begin{array}{c}\text { Postma et al. } \\
{[5]}\end{array}$ & 2005 & 12 & 42 & $\begin{array}{l}\text { 12, } R Y R 2 \text {-associated } \\
\text { cases }\end{array}$ & $\begin{array}{l}1(8 \%) \text { SCD over } \\
\text { median of } 6 \text { years }\end{array}$ & $\begin{array}{l}\text { Patients with } R Y R 2 \text { variants } \\
\text { have a significant resting } \\
\text { sinus bradycardia. }\end{array}$ \\
\hline $\begin{array}{c}\text { Hayashi et al. } \\
\text { [9] }\end{array}$ & 2009 & 50 & 51 & $12 \pm 8$ & $\begin{array}{l}27 \text { patients over } \\
7.9 \pm 4.9 \text { years }\end{array}$ & $\begin{array}{c}\text { Risk factors for arrhythmic } \\
\text { events include younger age } \\
\text { at diagnosis and absence of } \\
\beta \text {-blocker therapy }\end{array}$ \\
\hline $\begin{array}{l}\text { van der Werf } \\
\text { et al. [19] }\end{array}$ & 2012 & 24 & $\begin{array}{l}116 \\
\text { (61 from } 1 \\
\text { family) }\end{array}$ & Not reported & $\begin{array}{l}4(22 \%) \text { probands } \\
\text { over a median of } \\
7.8 \text { years; } 2 \\
\text { relatives over a } \\
\text { period of } 6.7 \\
\text { years }\end{array}$ & $\begin{array}{l}\text { Relatives have marked } \\
\text { phenotypic diversity and } \\
\text { less severe phenotypes } \\
\text { compared with probands. }\end{array}$ \\
\hline $\begin{array}{l}\text { Kawamura } \\
\text { et al. [76] }\end{array}$ & 2013 & 50 & 0 & $10.2 \pm 7.3$ & $\begin{array}{c}5(19 \%) \\
\text { experienced } \\
\text { syncope over } \\
\text { mean follow-up } \\
\text { of } 48 \text { months }\end{array}$ & $\begin{array}{l}\text { Penetrance of CPVT } \\
\text { phenotype was significantly } \\
\text { higher in patients with } \\
\text { RYR2 variants among } \\
\text { Japanese CPVT patients. }\end{array}$ \\
\hline $\begin{array}{c}\text { Ohno et al. } \\
\text { [77] }\end{array}$ & 2015 & 36 & 0 & $9.7 \pm 4.6^{*}$ & Not reported & $\begin{array}{l}\text { Almost half of } R Y R 2 \\
\text { variants are de novo, and } \\
\text { others are more often } \\
\text { inherited from mothers than } \\
\text { fathers. }\end{array}$ \\
\hline $\begin{array}{l}\text { Roston et al. } \\
\text { [12] }\end{array}$ & 2015 & 170 & 56 & $10.8(6.8-13.2)$ & Not reported & $\begin{array}{c}\text { CPVT can have a malignant } \\
\text { phenotype and lengthy } \\
\text { delay to diagnosis, } \\
\text { probands are typically } \\
\text { severely affected. }\end{array}$ \\
\hline $\begin{array}{c}\text { Jiang et al. } \\
\text { [78] }\end{array}$ & 2018 & & 12 & $8.4 \pm 3.2$ & $\begin{array}{l}1 \text { SCD over } 0.92 \\
\quad \pm 0.8 \text { years }\end{array}$ & $\begin{array}{l}\text { Severe delay to diagnosis } \\
\text { and misdiagnosis of CPVT } \\
\text { are not uncommon in China. }\end{array}$ \\
\hline Li et al. [79] & 2019 & 5 & 2 & $6.2 \pm 1.3$ & $\begin{array}{l}\text { No events over } \\
\text { mean follow-up } \\
\text { of } 16.5 \text { months * }\end{array}$ & $\begin{array}{l}\text { First systematic study to } \\
\text { examine CASQ2-CPVT in } \\
\text { Chinese children identifying } \\
\text { three novel variants. }\end{array}$ \\
\hline Ng et al. [25] & 2020 & 36 & 76 & $7.9 \pm 3.3$, probands only & Not reported & $\begin{array}{l}\text { Patients with pathogenic } \\
\text { CASQ2 heterozygous } \\
\text { variants may manifest } \\
\text { CPVT phenotype. }\end{array}$ \\
\hline $\begin{array}{l}\text { Kallas et al. } \\
\text { [20] }\end{array}$ & 2021 & 106 & 27 & $11(7-13.5)$ & $\begin{array}{l}44(33 \%) \text { inclusive } \\
\text { of a 3\% mortality } \\
\text { rate over 6-years } \\
\text { (3-11) after time } \\
\text { of symptom-onset }\end{array}$ & $\begin{array}{l}\text { Proband status, but not age } \\
\text { of symptom-onset or male } \\
\text { sex, independently } \\
\text { predicted an earlier-onset of } \\
\text { cardiac events. }\end{array}$ \\
\hline
\end{tabular}

Continuous variables were presented as mean with standard deviation $( \pm \mathrm{SD})$, median with interquartile range (IQR) where applicable; $\mathrm{SCD}=$ sudden cardiac death; ${ }^{\dagger}$ Cardiac events are inclusive of cardiac arrest, arrhythmia-induced syncope and SCD during follow-up; * Calculated from data set. 
CPVT is relatively uncommon in infants, with the youngest age of symptom onset reported as 2 years of age [10], however sudden infant death syndrome potentially caused by CPVT has previously been reported in two infants harbouring RYR2 gain of function missense variants [80]. Children can be misdiagnosed as epileptic prior to a CPVT diagnosis, due to a clinical presentation of seizures and exertion or emotion induced syncope $[1,9,81]$. Interestingly, $R Y R 2$ variants have also been linked to epilepsy $[82,83]$. Patients can experience a delay in diagnosis due to arrhythmogenic syncope being misdiagnosed as benign vasovagal events. CPVT may also be misdiagnosed as LQTS since patients may present with similar symptoms, inclusive of exercise-induced syncope, and SUD at similar ages [84,85]. The failure to perform an EST for the evaluation of patients with exertion or emotional induced symptoms or the misinterpretation of an EST can lead to missed or delayed diagnoses [86]. Although, polymorphic VT (occurring in the setting of prolonged QT in LQTS) are features of both diseases, LQTS does not induce progressive ventricular ectopy (monomorphic premature ventricular complexes (PVCs) $\rightarrow$ PVCs in bigeminy or couplets $\rightarrow$ bidirectional or polymorphic VT) on a treadmill test. Further clinical investigation including resting ECG, inclusion of EST in immediate post sudden cardiac arrest evaluation, and genetic testing can help with the differentiation of both diseases [84]. Andersen-Tawil Syndrome (ATS), a KCNJ2-associated disease, may be mistaken for CPVT due to the presence of ventricular ectopy and bidirectional VT during exercise stress testing in both conditions. However, the ATS phenotype is also accompanied by characteristic orthopedic and facial deformities which is a clear differentiating factor from CPVT [39], especially in the absence of a prolonged QT interval and U-waves on a resting ECG [87].

In addition to ventricular arrhythmias, a proportion of CPVT cases have supraventricular arrhythmias [19]. Based on one report of CPVT patients, 38\% of CPVT cases were associated with atrial fibrillation or atrial flutter [75]. In another report, $19 \%$ of patients were described to have atrial fibrillation and junctional tachycardia [1]. CPVT patients may also have sinus node dysfunction and inducible atrial arrhythmias, suggesting that the disease phenotype is not limited to ventricular arrhythmias but might also involve the sinus node and atrium [75].

\section{Diagnosis}

In CPVT, the resting ECG often shows normal sinus rhythm or sinus bradycardia without conduction abnormalities [19]. Cardiac imaging tests such as echocardiograms and cardiac magnetic resonance imaging are also normal [6]. Therefore, CPVT should be considered in the differential diagnosis in patients with unexplained life-threatening arrhythmias with a normal resting ECG and imaging [88]. In addition, the expert consensus recommendations state that one of the following should be present to make a CPVT diagnosis [6]:

- An unexplained catecholamine-induced bidirectional VT or polymorphic ventricular premature beats (VPBs), or VT in an individual younger than 40 years;

- A patient (index case or family member) with a pathogenic variant in a CPVT-related gene (see Genetic Etiology for details); and

- $\quad$ Family members of a CPVT index case with a normal heart who manifest exerciseinduced PVCs or bidirectional or polymorphic VT.

An exercise stress test (EST) is the current standard to diagnose CPVT. Ventricular arrhythmias are provoked in $80 \%$ of symptomatic probands, although mild forms of ventricular ectopy may be overlooked $[1,7,10]$. Typically, PVCs occur around a heart rate of 100-120 beats per minute, and progress to bigeminy, couplets, and non-sustained polymorphic or bidirectional VT as heart rate increases [11]. Ventricular arrhythmias in CPVT are often initiated in the right ventricular outflow tract in pediatric patients [10]. A normal or near normal EST does not reliably refute the diagnosis of CPVT, especially when the pre-test probability of the condition is moderate to high [89]. Van der Werf et al. reported that $50 \%$ of patients who were unaffected at their first cardiac examination 
developed a phenotype during re-evaluation at a median follow-up of 1.6 years [19]. We recently reported a new EST "Burst" protocol that unmasked new or more complex arrhythmias in children not identified by standard EST alone [90]. This is based on the concept that a sudden sprint is more likely to induce CPVT than a gradual graded protocol, like the Bruce protocol. In patients who are too young to run on a treadmill or not able to reach sufficient heart rates during exercise, an ambulatory ECG monitor or a Holter monitor can be diagnostic [91]. Intravenous epinephrine infusion test, which mimics endogenous catecholamine release, has also been proposed as an alternative to EST for diagnosing CPVT. However, a study of 81 CPVT patients showed that in comparison to EST, pharmacological provocation with epinephrine only had a $28 \%$ sensitivity and therefore should not be part of routine practice [92].

\section{Genetic Testing Guidelines in CPVT}

Genetic testing has two main utilities in CPVT: (1) to confirm a clinical diagnosis; and (2) to inform cascade family screening. Importantly, since $R Y R 2$ and CASQ2 variants are identified in around $60 \%$ of CPVT cases [12,93], and the background rate of rare benign variation in $R Y R 2$ approaches 3\% [94,95], genetic testing should not be used to rule out the diagnosis when clinical suspicion exists or rule it in when the variant is not definitively pathogenic. The most recent expert consensus statement on genetic testing guidelines in channelopathies recommend comprehensive $R Y R 2$ and CASQ2 targeted CPVT genetic testing for patients with a clinical index of suspicion for CPVT based on clinical history, family history and development of electrocardiographic phenotype with provocative testing. Additionally, variant-specific testing in relatives of index cases with an identified CPVT-causative variant, is also recommended [96]. Approximately $8 \%$ of children with CPVT will have $\geq 2$ variants, which poses challenges with risk stratification, highlighting the importance of family based genetic counselling [45]. Therefore, ordering broader genetic panels is unlikely to be helpful unless the phenotype is overlapping or syndromic features are present since variant interpretation becomes challenging.

$R Y R 2$-associated CPVT variants often cluster in four mutational hotspots reported by Priori and Chen based on aggregate data from the literature: Hotspot I (amino acids $44-466 ; 18 \%$ of mutations) located in the N-terminus domain (amino acid 77-446); Hotspot II (2246-2534; 19\% of mutations) located in the central domain (2246-2534); Hotspot III (3778-4201; 22\% of mutations) and Hotspot IV (4497-4959; $22 \%$ of mutations) located in the C-terminus domain (3778-4959) [49,97]. Guidelines on the utility of genetic testing in CPVT do not fully address all the important nuances of sequencing nor the interpretation of a variant. A newly devised "phenotype-enhanced" scoring system for $R Y R 2$ variants has recently been described, which factors the pre-test probability of CPVT into the assignment of pathogenicity [95]. In addition, more than 24 pathogenic $C A S Q 2$ variants associated with CPVT have been identified to date [79]. Consanguineous family members are typically tested for $C A S Q 2$ variants. Pathogenic CASQ2 variants have not only been reported in an autosomal recessive pattern, but also in heterozygotes with an autosomal dominant inheritance pattern [25]. The putative mechanism of CASQ2 heterozygous CPVT is a failure of back-to-back dimerization of mutant CASQ2, an effect that may be variant specific, and result in generally mild CPVT [25].

\section{Therapy and Management}

\section{1. $\beta$-Blockers}

$\beta$-blockers are the mainstay of treatment in CPVT patients [6]. $\beta$-blockers act by inhibiting $\beta$-adrenergic mediated-activation of RyR2 channels. $\beta$-blockers alone may offer incomplete protection. A meta-analysis of 11 studies comprising 403 mostly young CPVT patients, reported $\beta$-blocker use in $88 \%$ of symptomatic patients with an eight-year arrhythmic (syncope, ACA, SCD), near-fatal (ACA, SCD), and fatal event rates of $37.2 \%, 15.3 \%$, and $6.4 \%$, respectively [97]. Although $\beta$-blockers have been effective for the majority of patients, the arrhythmic event rate on $\beta$-blocker remains significant. Therefore, a stepwise 
addition of other therapeutic options is recommended when $\beta$-blockers fail [97]. Another pediatric cohort study found that arrhythmic syncope or cardiac arrest while on $\beta$-blockers occurred in $13 \%$ of CPVT patients [31]. Non-adherence is a major problem, especially in children [12]. Nadolol, a non-selective $\beta$-blocker, is preferred and should be prescribed at a dosage of at least $1-2 \mathrm{mg} / \mathrm{kg}$ (divided into two doses/day). Hayashi et al. were the first to describe lower cardiac event rates in patients treated with nadolol versus other $\beta$-blockers among patients diagnosed at a median age of $15 \pm 10$ years [9]. Another study reported decreased incidence and severity of ventricular arrhythmias in patients during treatment with nadolol relative to $\beta_{1}$-selective $\beta$-blockers [98]. Non-selective $\beta$-blockers should be prescribed to all CPVT patients except for those who have contraindications or intolerance, irrespective of sinus node dysfunction.

\subsection{Flecainide}

When $\beta$-blockers are ineffective at suppressing ventricular ectopy, flecainide is usually prescribed as combination therapy. Flecainide is a class $1 \mathrm{c}$ antiarrhythmic and potent $\mathrm{Na}^{+}$channel blocker and is prescribed in divided doses of 100-300 mg/day. Flecainide in combination with $\beta$-blockers has been shown to reduce exercise-induced ventricular arrhythmias in children and adults with breakthrough events on $\beta$-blockers alone $[13,14]$. Another study showed that flecainide prevented recurring ICD shocks in addition to exercise-induced ventricular arrhythmias in patients with CASQ2 associated CPVT [16]. Padfield et al. described a small series suggesting that flecainide monotherapy can be considered in low-risk CPVT patients intolerant of $\beta$-blockade, however further data are needed to confirm the protectiveness of this approach [99]. The mechanism of action of flecainide in CPVT remains debated in the literature. An early mechanistic study found that flecainide directly interacts with RyR2 and inhibits its activity [15]. This theory is supported by evidence presented in a recent study by Kryshtal and colleagues [59]. However, Bannister et al. suggested that flecainide does not have a direct interaction with RyR2, rather it affects the cytoplasmic proteins associated with RyR2 [100].

\subsection{Left Cardiac Sympathetic Denervation}

LCSD is an alternative therapy in patients when $\beta$-blockers are poorly tolerated or fail to prevent recurrent syncope, cardiac arrest or ICD shocks [101]. LCSD involves removal of the lower half of the left stellate ganglion (T1), along with the thoracic ganglia T2 through T4, in order to reduce the sensitivity of the heart to catecholamines [102]. The reduction in the release of the catecholamine norepinephrine by sympathetic neurons in ventricular myocytes contributes to LCSD's antiarrhythmic and antifibrillatory effects [102]. In a large cohort comprising 63 patients, LCSD was associated with a decrease in cardiac events and a decrease in the rate of ICD shocks [18]. LCSD is a promising therapy in CPVT, although its lack of accessibility worldwide will remain a limitation to its widespread implementation. Further data on indication and long-term outcomes would be helpful.

\subsection{Implantable Cardioverter Defibrillators}

Current North American and European guidelines recommend that an ICD be reserved for CPVT patients with prior SCA, or those with refractory ventricular arrhythmias on combination pharmacological therapy $[103,104]$. ICDs may be considered in children who experience breakthrough arrhythmic events or sustained VT or VF despite antiarrhythmic treatment [6]. However, ICDs can be ineffective and pro-arrhythmic in young CPVT patients, with deaths being reported despite appropriate ICD therapy [105-107]. Appropriate shocks have been reported to be ineffective at terminating sustained VT [108]. Implantation of an ICD poses a technical challenge in pediatric patients given the high rate of device related complications and inappropriate shocks $[108,109]$, which may be a consequence of supraventricular tachycardia such as atrial arrhythmias $[9,11]$. Both appropriate and inappropriate discharges can cause catecholamine surges which can lead to electrical storm and potentially life-threatening arrhythmias [110]. Other chal- 
lenges with implanting ICDs in children include optimal programming, the psychological trauma of repeated shocks, high risk of inappropriate therapies due to atrial arrhythmias, and life-long burden of mechanical and infectious complication risk. Therefore, determining which patients benefit from ICDs in CPVT is an urgent area of need.

\subsection{Lifestyle Management: Sport Participation}

Given that adverse cardiac events often manifest during adrenergic stress, patients and families must be advised on sports participation. The European Society of Cardiology guidelines for management of patients with SCD recommend that CPVT patients avoid competitive sports, strenuous exercise, and exposure to stressful environments to avoid the consequences of adrenergic stimulation [103]. These restrictions can have a psychological impact on children. In fact, a study on competitive sports participation in CPVT patients found no significant difference in incidence of cardiac events between athletes and nonathletes, indicating that the risk of sports participation may be acceptable among informed athletes adhering to guideline recommended therapy [111].

\subsection{Other Therapeutic Interventions}

Another intervention which has been studied in CPVT but is not part of any routine therapeutic regiment is dantrolene. Dantrolene, commonly used for malignant hyperthermia, affects $\mathrm{Ca}^{2+}$ flux across the SR and cardiomyocyte function in failing hearts. In CPVT mouse models, dantrolene was effective in inhibiting inducible VT, and reduced diastolic $\mathrm{Ca}^{2+}$ sparks and DADs [112] by correcting defective inter-domain interactions between the N-terminal and central domain of RyR2 [112-114]. A study by Penttinen et al. showed that dantrolene reduced the number of PVCs by $75 \%$ in four of six patients with variants in the $\mathrm{N}$-terminal/central terminal but had no effect in patients with variants in the transmembrane domain [115]. Although dantrolene has shown to be effective in some patients, data is limited and further investigation is warranted before this therapy can be recommended in CPVT.

There are few acute treatment options which may be considered in CPVT, however these typically vary from patient to patient. Standard defibrillation therapy (either an automated external defibrillator or ICD) can be fatal due to a potential surge in catecholamines which can lead to generation of DADs and consequent arrhythmia $[105,108]$. Therefore, sedation, intubation, and stabilization of the patient's rhythm is of paramount importance. In some cases, a magnet can be used to reduce the risk of ICD storms [116]. Intravenous $\beta$-blockers are another therapeutic option, which can effectively resolve arrhythmias in most patients. IV-esmolol is a common therapeutic option due to its intravenous formulation and short half-life [116]. Flecainide may also be used intravenously, however its efficacy in the acute setting is largely unknown. Finally, propranolol has also been shown to be efficacious in the management of acute VT [117]. Overall, these treatment options stem from CPVT's disease mechanism and extrapolation from chronic therapies, yet no data is available to support their use in the acute setting.

Gene therapy is an exciting novel area of research on CPVT therapeutics, albeit in its infancy. A recent study by Bezzerides et al. showed that adeno-associated virus mediated CaMKII peptide inhibitor delivery to the heart effectively suppressed CPVT-associated arrhythmias in a murine CPVT model [118]. These inhibitory peptides also successfully reversed arrhythmias in hiPSC-CM models of CPVT [118]. Additionally, CRISPR/Cas9 gene editing has also been used in hiPSC CPVT disease models to evaluate drug sensitivities of pathogenic variants $[119,120]$.

\section{Conclusions}

CPVT is a rare and lethal inherited arrhythmia disease characterized by VT in the absence of structural heart disease often presenting in childhood. The knowledge surrounding disease mechanism, diagnosis, treatment, and prognosis has improved over the last two decades, but several gaps remain. These include ongoing questions surrounding 
the primary mechanism of arrhythmia and target of flecainide, safety of physical activity while on therapy, risk stratification to inform ICD and ancillary therapy decision-making, and the potential role of genetic modifiers in explaining variability in disease penetrance and expressivity, especially in pediatric CPVT. Centers leading large registries need to develop translational science opportunities for the clinician-scientist aimed at addressing the interplay between genotype and these gaps.

Funding: This research received no external funding.

Institutional Review Board Statement: Not applicable.

Informed Consent Statement: Not applicable.

Data Availability Statement: Not applicable.

Conflicts of Interest: The authors declare no conflict of interest.

\section{References}

1. Leenhardt, A.; Lucet, V.; Denjoy, I.; Grau, F.; Ngoc, D.D.; Coumel, P. Catecholaminergic Polymorphic Ventricular Tachycardia in Children A 7-Year Follow-up of 21 Patients. Circulation 1995, 91, 1512-1519. [CrossRef]

2. Swan, H.; Piippo, K.; Viitasalo, M.; Heikkilä, P.; Paavonen, T.; Kainulainen, K.; Kere, J.; Keto, P.; Kontula, K.; Toivonen, L. Arrhythmic disorder mapped to chromosome $1 \mathrm{q} 42-\mathrm{q} 43$ causes malignant polymorphic ventricular tachycardia in structurally normal hearts. J. Am. Coll. Cardiol. 1999, 34, 2035-2042. [CrossRef]

3. Priori, S.G.; Napolitano, C.; Memmi, M.; Colombi, B.; Drago, F.; Gasparini, M.; DeSimone, L.; Coltorti, F.; Bloise, R.; Keegan, R.; et al. Clinical and Molecular Characterization of Patients With Catecholaminergic Polymorphic Ventricular Tachycardia. Circulation 2002, 106, 69-74. [CrossRef] [PubMed]

4. Bauce, B.; Rampazzo, A.; Basso, C.; Bagattin, A.; Daliento, L.; Tiso, N.; Turrini, P.; Thiene, G.; Danieli, G.A.; Nava, A. Screening for ryanodine receptor type 2 mutations in families with effort-induced polymorphic ventricular arrhythmias and sudden death. J. Am. Coll. Cardiol. 2002, 40, 341-349. [CrossRef]

5. Postma, A.V.; Denjoy, I.; Kamblock, J.; Alders, M.; Lupoglazoff, J.-M.; Vaksmann, G.; Dubosq-Bidot, L.; Sebillon, P.; Mannens, M.M.A.M.; Guicheney, P.; et al. Catecholaminergic polymorphic ventricular tachycardia: RYR2 mutations, bradycardia, and follow up of the patients. J. Med. Genet. 2005, 42, 863-870. [CrossRef] [PubMed]

6. Priori, S.G.; Wilde, A.A.; Horie, M.; Cho, Y.; Behr, E.; Berul, C.; Blom, N.; Brugada, J.; Chiang, C.-E.; Huikuri, H.; et al. HRS/EHRA/APHRS expert consensus statement on the diagnosis and management of patients with inherited primary arrhythmia syndromes: Document endorsed by HRS, EHRA, and APHRS in May 2013 and by ACCF, AHA, PACES, and AEPC in June 2013. Heart Rhythm 2013, 10, 1932-1963. [CrossRef]

7. Priori, S.G.; Napolitano, C.; Tiso, N.; Memmi, M.; Vignati, G.; Bloise, R.; Sorrentino, V.; Danieli, G.A. Mutations in the Cardiac Ryanodine Receptor Gene (hRyR2) Underlie Catecholaminergic Polymorphic Ventricular Tachycardia. Circulation 2001, 103, 196-200. [CrossRef]

8. Lahat, H.; Pras, E.; Olender, T.; Avidan, N.; Ben-Asher, E.; Man, O.; Levy-Nissenbaum, E.; Khoury, A.; Lorber, A.; Goldman, B.; et al. A missense mutation in a highly conserved region of CASQ2 is associated with autosomal recessive catecholamine-induced polymorphic ventricular tachycardia in Bedouin families from Israel. Am. J. Hum. Genet. 2001, 69, 1378-1384. [CrossRef] [PubMed]

9. Hayashi, M.; Denjoy, I.; Extramiana, F.; Maltret, A.; Buisson, N.R.; Lupoglazoff, J.M.; Klug, D.; Hayashi, M.; Takatsuki, S.; Villain, E.; et al. Incidence and Risk Factors of Arrhythmic Events in Catecholaminergic Polymorphic Ventricular Tachycardia. Circulation 2009, 119, 2426-2434. [CrossRef]

10. Sumitomo, N.; Harada, K.; Nagashima, M.; Yasuda, T.; Nakamura, Y.; Aragaki, Y.; Saito, A.; Kurosaki, K.; Jouo, K.; Koujiro, M.; et al. Catecholaminergic polymorphic ventricular tachycardia: Electrocardiographic characteristics and optimal therapeutic strategies to prevent sudden death. Heart 2003, 89, 66-70. [CrossRef]

11. Sy, R.W.; Gollob, M.; Klein, G.J.; Yee, R.; Skanes, A.C.; Gula, L.J.; Leong-Sit, P.; Gow, R.M.; Green, M.S.; Birnie, D.H.; et al. Arrhythmia characterization and long-term outcomes in catecholaminergic polymorphic ventricular tachycardia. Heart Rhythm 2011, 8, 864-871. [CrossRef] [PubMed]

12. Roston, T.M.; Vinocur, J.M.; Maginot, K.R.; Mohammed, S.; Salerno, J.C.; Etheridge, S.P.; Cohen, M.; Hamilton, R.M.; Pflaumer, A.; Kanter, R.J.; et al. Catecholaminergic polymorphic ventricular tachycardia in children: Analysis of therapeutic strategies and outcomes from an international multicenter registry. Circ. Arrhythm. Electrophysiol. 2015, 8, 633-642. [CrossRef]

13. van der Werf, C.; Kannankeril, P.J.; Sacher, F.; Krahn, A.D.; Viskin, S.; Leenhardt, A.; Shimizu, W.; Sumitomo, N.; Fish, F.A.; Bhuiyan, Z.A.; et al. Flecainide therapy reduces exercise-induced ventricular arrhythmias in patients with catecholaminergic polymorphic ventricular tachycardia. J. Am. Coll. Cardiol. 2011, 57, 2244-2254. [CrossRef] [PubMed] 
14. Kannankeril, P.J.; Moore, J.P.; Cerrone, M.; Priori, S.G.; Kertesz, N.J.; Ro, P.S.; Batra, A.S.; Kaufman, E.S.; Fairbrother, D.L.; Saarel, E.V.; et al. Efficacy of Flecainide in the Treatment of Catecholaminergic Polymorphic Ventricular Tachycardia: A Randomized Clinical Trial. JAMA Cardiol. 2017, 2, 759-766. [CrossRef] [PubMed]

15. Watanabe, H.; Chopra, N.; Laver, D.; Hwang, H.S.; Davies, S.; E Roach, D.; Duff, H.; Roden, D.M.; Wilde, A.A.M.; Knollmann, B.C. Flecainide prevents catecholaminergic polymorphic ventricular tachycardia in mice and humans. Nat. Med. 2009, 15, 380-383. [CrossRef] [PubMed]

16. Khoury, A.; Marai, I.; Suleiman, M.; Blich, M.; Lorber, A.; Gepstein, L.; Boulos, M. Flecainide therapy suppresses exercise-induced ventricular arrhythmias in patients with CASQ2-associated catecholaminergic polymorphic ventricular tachycardia. Heart Rhythm 2013, 10, 1671-1675. [CrossRef]

17. van der Werf, C.; Lieve, K.V.; Bos, J.M.; Lane, C.M.; Denjoy, I.; Roses-Noguer, F.; Aiba, T.; Wada, Y.; Ingles, J.; Leren, I.S.; et al. Implantable cardioverter-defibrillators in previously undiagnosed patients with catecholaminergic polymorphic ventricular tachycardia resuscitated from sudden cardiac arrest. Eur. Heart J. 2019, 40, 2953-2961. [CrossRef]

18. De Ferrari, G.M.; Dusi, V.; Spazzolini, C.; Bos, J.M.; Abrams, D.J.; Berul, C.I.; Crotti, L.; Eldar, M.; Kharlap, M.; Khoury, A.; et al. Clinical Management of Catecholaminergic Polymorphic Ventricular Tachycardia: The Role of Left Cardiac Sympathetic Denervation. Circulation 2015, 131, 2185-2193. [CrossRef]

19. van der Werf, C.; Nederend, I.; Hofman, N.; van Geloven, N.; Ebink, C.; Frohn-Mulder, I.M.; Alings, A.M.; Bosker, H.A.; Bracke, F.A.; van den Heuvel, F.; et al. Familial evaluation in catecholaminergic polymorphic ventricular tachycardia: Disease penetrance and expression in cardiac ryanodine receptor mutation-carrying relatives. Circ. Arrhythm. Electrophysiol. 2012, 5, 748-756. [CrossRef]

20. Kallas, D.; Roston, T.M.; Franciosi, S.; Brett, L.; Lieve, K.V.; Kwok, S.-Y.; Kannankeril, P.J.; Krahn, A.D.; LaPage, M.J.; Etheridge, S.; et al. An Evaluation of Age at Symptom-Onset, Proband Status and Sex as Predictors of Disease Severity in Pediatric Catecholaminergic Polymorphic Ventricular Tachycardia. Heart Rhythm 2021. [CrossRef]

21. Berg, K.J. Multifocal ventricular extrasytoles with adams-stokes syndrome in siblings. Am. Heart J. 1960, 60, 965-970. [CrossRef]

22. Reid, D.S.; Tynan, M.; Braidwood, L.; Fitzgerald, G.R. Bidirectional tachycardia in a child. A study using his bundle electrography. Heart 1975, 37, 339-344. [CrossRef] [PubMed]

23. Laitinen, P.J.; Brown, K.M.; Piippo, K.; Swan, H.; Devaney, J.M.; Brahmbhatt, B.; Donarum, E.A.; Marino, M.; Tiso, N.; Viitasalo, M.; et al. Mutations of the cardiac ryanodine receptor (RyR2) gene in familial polymorphic ventricular tachycardia. Circulation 2001, 103, 485-490. [CrossRef]

24. Lanner, J.; Georgiou, D.K.; Joshi, A.D.; Hamilton, S.L. Ryanodine receptors: Structure, expression, molecular details, and function in calcium release. Cold Spring Harb Perspect. Biol. 2010, 2, a003996. [CrossRef]

25. Ng, K.; Titus, E.W.; Lieve, K.V.; Roston, T.M.; Mazzanti, A.; Deiter, F.H.; Denjoy, I.; Ingles, J.; Till, J.; Robyns, T.; et al. An International Multicenter Evaluation of Inheritance Patterns, Arrhythmic Risks, and Underlying Mechanisms of CASQ2 -Catecholaminergic Polymorphic Ventricular Tachycardia. Circulation 2020, 142, 932-947. [CrossRef]

26. Garcia-Elias, A.; Benito, B. Ion Channel Disorders and Sudden Cardiac Death. Int. J. Mol. Sci. 2018, 19, 692. [CrossRef] [PubMed]

27. Nyegaard, M.; Overgaard, M.T.; Søndergaard, M.T.; Vranas, M.; Behr, E.; Hildebrandt, L.L.; Lund, J.; Hedley, P.; Camm, A.J.; Wettrell, G.; et al. Mutations in calmodulin cause ventricular tachycardia and sudden cardiac death. Am. J. Hum. Genet. 2012, 91, 703-712. [CrossRef] [PubMed]

28. Roux-Buisson, N.; Cacheux, M.; Fourest-Lieuvin, A.; Fauconnier, J.; Brocard, J.; Denjoy, I.; Durand, P.; Guicheney, P.; Kyndt, F.; Leenhardt, A.; et al. Absence of triadin, a protein of the calcium release complex, is responsible for cardiac arrhythmia with sudden death in human. Hum. Mol. Genet. 2012, 21, 2759-2767. [CrossRef] [PubMed]

29. Kirchhefer, U.; Wehrmeister, D.; Postma, A.; Pohlentz, G.; Mormann, M.; Kucerova, D.; Müller, F.U.; Schmitz, W.; Schulze-Bahr, E.; Wilde, A.A.; et al. The human CASQ2 mutation $\mathrm{K} 206 \mathrm{~N}$ is associated with hyperglycosylation and altered cellular calcium handling. J. Mol. Cell. Cardiol. 2010, 49, 95-105. [CrossRef]

30. Gray, B.; Bagnall, R.D.; Lam, L.; Ingles, J.; Turner, C.; Haan, E.; Davis, A.; Yang, P.-C.; Clancy, C.E.; Sy, R.W.; et al. A novel heterozygous mutation in cardiac calsequestrin causes autosomal dominant catecholaminergic polymorphic ventricular tachycardia. Heart Rhythm 2016, 13, 1652-1660. [CrossRef]

31. Roston, T.M.; Yuchi, Z.; Kannankeril, P.J.; Hathaway, J.; Vinocur, J.M.; Etheridge, S.P.; E Potts, J.; Maginot, K.R.; Salerno, J.C.; Cohen, I.M.; et al. The clinical and genetic spectrum of catecholaminergic polymorphic ventricular tachycardia: Findings from an international multicentre registry. Europace 2018, 20, 541-547. [CrossRef] [PubMed]

32. Bhuiyan, Z.A.; Hamdan, M.A.; Shamsi, E.T.; Postma, A.V.; Mannens, M.M.; Wilde, A.A.M.; Al-Gazali, L. A novel early onset lethal form of catecholaminergic polymorphic ventricular tachycardia maps to chromosome 7p14-p22. J. Cardiovasc. Electrophysiol. 2007, 18, 1060-1066. [CrossRef] [PubMed]

33. Webster, G.; Aburawi, E.H.; A Chaix, M.; Chandler, S.; Foo, R.; Islam, A.K.M.M.; A E Kammeraad, J.; Rioux, J.D.; Al-Gazali, L.; Sayeed, Z.; et al. Life-threatening arrhythmias with autosomal recessive TECRL variants. Europace 2020, 23, 781-788. [CrossRef] [PubMed]

34. Kalscheur, M.M.; Vaidyanathan, R.; Orland, K.M.; Abozeid, S.; Fabry, N.; Maginot, K.R.; January, C.T.; Makielski, J.C.; Eckhardt, L.L. KCNJ2 mutation causes an adrenergic-dependent rectification abnormality with calcium sensitivity and ventricular arrhythmia. Heart Rhythm 2014, 11, 885-894. [CrossRef] [PubMed]

35. Sumitomo, N. Current topics in catecholaminergic polymorphic ventricular tachycardia. J. Arrhythm. 2016, 32, 344-351. [CrossRef] 
36. Laurent, G.; Saal, S.; Amarouch, M.Y.; Béziau, D.M.; Marsman, R.F.; Faivre, L.; Barc, J.; Dina, C.; Bertaux, G.; Barthez, O.; et al. Multifocal ectopic Purkinje-related premature contractions: A new SCN5A-related cardiac channelopathy. J. Am. Coll. Cardiol. 2012, 60, 144-156. [CrossRef]

37. Swan, H.; Amarouch, M.Y.; Leinonen, J.; Marjamaa, A.; Kucera, J.P.; Laitinen-Forsblom, P.J.; Lahtinen, A.M.; Palotie, A.; Kontula, K.; Toivonen, L.; et al. Gain-of-function mutation of the SCN5A gene causes exercise-induced polymorphic ventricular arrhythmias. Circ. Cardiovasc. Genet. 2014, 7, 771-781. [CrossRef]

38. Imberti, J.F.; Underwood, K.; Mazzanti, A.; Priori, S.G. Clinical Challenges in Catecholaminergic Polymorphic Ventricular Tachycardia. Heart Lung. Circ. 2016, 25, 777-783. [CrossRef]

39. Barajas-Martinez, H.; Hu, D.; Ontiveros, G.; Caceres, G.; Desai, M.; Burashnikov, E.; Scaglione, J.; Antzelevitch, C. Biophysical and molecular characterization of a novel de novo KCNJ2 mutation associated with Andersen-Tawil syndrome and catecholaminergic polymorphic ventricular tachycardia mimicry. Circ. Cardiovasc. Genet. 2011, 4, 51-57. [CrossRef]

40. Wangüemert, F.; Calero, C.B.; Pérez, C.; Campuzano, O.; Beltran-Alvarez, P.; Scornik, F.S.; Iglesias, A.; Berne, P.; Allegue, C.; Hernandez, P.M.R.; et al. Clinical and molecular characterization of a cardiac ryanodine receptor founder mutation causing catecholaminergic polymorphic ventricular tachycardia. Heart Rhythm 2015, 12, 1636-1643. [CrossRef]

41. Kolder, I.; Tanck, M.; Postema, P.G.; Barc, J.; Sinner, M.F.; Zumhagen, S.; Husemann, A.; Stallmeyer, B.; Koopmann, T.T.; Hofman, N.; et al. Analysis for Genetic Modifiers of Disease Severity in Patients With Long-QT Syndrome Type 2. Circ. Cardiovasc. Genet. 2015, 8, 447-456. [CrossRef] [PubMed]

42. Crotti, L.; Lahtinen, A.M.; Spazzolini, C.; Mastantuono, E.; Monti, M.C.; Morassutto, C.; Parati, G.; Heradien, M.; Goosen, A.; Lichtner, P.; et al. Genetic Modifiers for the Long-QT Syndrome: How Important Is the Role of Variants in the 3'Untranslated Region of KCNQ1? Circ. Cardiovasc. Genet. 2016, 9, 330-339. [CrossRef] [PubMed]

43. Chai, S.; Wan, X.; Ramirez-Navarro, A.; Tesar, P.; Kaufman, E.S.; Ficker, E.; George, A.L.; Deschênes, I. Physiological genomics identifies genetic modifiers of long QT syndrome type 2 severity. J. Clin. Invest. 2018, 128, 1043-1056. [CrossRef] [PubMed]

44. Marian, A.J. Modifier genes for hypertrophic cardiomyopathy. Curr. Opin. Cardiol. 2002, 17, 242-252. [CrossRef] [PubMed]

45. Roston, T.M.; Haji-Ghassemi, O.; LaPage, M.J.; Batra, A.S.; Bar-Cohen, Y.; Anderson, C.; Lau, Y.R.; Maginot, K.; Gebauer, R.A.; Etheridge, S.P.; et al. Catecholaminergic polymorphic ventricular tachycardia patients with multiple genetic variants in the PACES CPVT Registry. PLoS ONE 2018, 13, e0205925. [CrossRef] [PubMed]

46. Lahrouchi, N.; Tadros, R.; Crotti, L.; Mizusawa, Y.; Postema, P.G.; Beekman, L.; Walsh, R.; Hasegawa, K.; Barc, J.; Ernsting, M.; et al. Transethnic Genome-Wide Association Study Provides Insights in the Genetic Architecture and Heritability of Long QT Syndrome. Circulation 2020, 142, 324-338. [CrossRef]

47. Sutanto, H.; Lyon, A.; Lumens, J.; Schotten, U.; Dobrev, D.; Heijman, J. Cardiomyocyte calcium handling in health and disease: Insights from in vitro and in silico studies. Prog. Biophys. Mol. Biol. 2020, 157, 54-75. [CrossRef]

48. Györke, I.; Hester, N.; Jones, L.R.; Györke, S. The role of calsequestrin, triadin, and junctin in conferring cardiac ryanodine receptor responsiveness to luminal calcium. Biophys. J. 2004, 86, 2121-2128. [CrossRef]

49. Priori, S.G.; Chen, S.R.W. Inherited dysfunction of sarcoplasmic reticulum Ca2+ handling and arrhythmogenesis. Circ. Res. 2011, 108, 871-883. [CrossRef]

50. Kass, R.S.; Tsien, R.W. Fluctuations in membrane current driven by intracellular calcium in cardiac Purkinje fibers. Biophys. J. 1982, 38, 259-269. [CrossRef]

51. Orchard, C.H.; Eisner, D.A.; Allen, D.G. Oscillations of intracellular Ca2+ in mammalian cardiac muscle. Nature 1983, 304, 735-738. [CrossRef]

52. Lohse, M.J.; Engelhardt, S.; Eschenhagen, T. What is the role of beta-adrenergic signaling in heart failure? Circ. Res. 2003, 93, 896-906. [CrossRef]

53. Kamp, T.J.; Hell, J.W. Regulation of cardiac L-type calcium channels by protein kinase A and protein kinase C. Circ. Res. 2000, 87, 1095-1102. [CrossRef]

54. Simmerman, H.K.; Jones, L.R. Phospholamban: Protein structure, mechanism of action, and role in cardiac function. Physiol. Rev. 1998, 78, 921-947. [CrossRef]

55. Layland, J.; Solaro, R.J.; Shah, A.M. Regulation of cardiac contractile function by troponin I phosphorylation. Cardiovasc. Res. 2005, 66, 12-21. [CrossRef] [PubMed]

56. Kunst, G.; Kress, K.R.; Gruen, M.; Uttenweiler, D.; Gautel, M.; Fink, R.H.A. Myosin binding protein C, a phosphorylationdependent force regulator in muscle that controls the attachment of myosin heads by its interaction with myosin S2. Circ. Res. 2000, 86, 51-58. [CrossRef] [PubMed]

57. Chen, L.; Sampson, K.J.; Kass, R.S. Cardiac Delayed Rectifier Potassium Channels in Health and Disease. Card Electrophysiol. Clin. 2016, 8, 307-322. [CrossRef]

58. Bers, D.M. Cardiac excitation-contraction coupling. Nature 2002, 415, 198-205. [CrossRef] [PubMed]

59. Kryshtal, D.O.; Blackwell, D.J.; Egly, C.L.; Smith, A.N.; Batiste, S.M.; Johnston, J.N.; Laver, D.R.; Knollmann, B.C. RYR2 Channel Inhibition Is the Principal Mechanism of Flecainide Action in CPVT. Circ. Res. 2021, 128, 321-331. [CrossRef]

60. Wleklinski, M.J.; Kannankeril, P.J.; Knollmann, B.C. Molecular and tissue mechanisms of catecholaminergic polymorphic ventricular tachycardia. J. Physiol. 2020, 598, 2817-2834. [CrossRef] [PubMed]

61. Willegems, K.; Efremov, R.G. Structural Details of the Ryanodine Receptor Calcium Release Channel and Its Gating Mechanism. Adv. Exp. Med. Biol. 2017, 981, 179-204. 
62. Jiang, D.; Xiao, B.; Yang, D.; Wang, R.; Choi, P.; Zhang, L.; Cheng, H.; Chen, S.R.W. RyR2 mutations linked to ventricular tachycardia and sudden death reduce the threshold for store-overload-induced Ca2+ release (SOICR). Proc. Natl. Acad. Sci. USA 2004, 101, 13062-13067. [CrossRef] [PubMed]

63. Liu, Y.; Kimlicka, L.; Hiess, F.; Tian, X.; Wang, R.; Zhang, L.; Jones, P.P.; Van Petegem, F.; Chen, S.R.W. The CPVT-associated RyR2 mutation G230C enhances store overload-induced Ca2+ release and destabilizes the N-terminal domains. Biochem. J. 2013, 454, 123-131. [CrossRef] [PubMed]

64. MacLennan, D.H.; Chen, S.R. Store overload-induced Ca2+ release as a triggering mechanism for CPVT and MH episodes caused by mutations in RYR and CASQ genes. J. Physiol. 2009, 587, 3113-3115. [CrossRef] [PubMed]

65. Wehrens, X.H.; Lehnart, S.E.; Huang, F.; Vest, J.A.; Reiken, S.R.; Mohler, P.J.; Sun, J.; Guatimosim, S.; Song, L.-S.; Rosemblit, N.; et al. FKBP12.6 deficiency and defective calcium release channel (ryanodine receptor) function linked to exercise-induced sudden cardiac death. Cell 2003, 113, 829-840. [CrossRef]

66. Xiao, J.; Tian, X.; Jones, P.P.; Bolstad, J.; Kong, H.; Wang, R.; Zhang, L.; Duff, H.; Gillis, A.M.; Fleischer, S.; et al. Removal of FKBP12.6 does not alter the conductance and activation of the cardiac ryanodine receptor or the susceptibility to stress-induced ventricular arrhythmias. J. Biol. Chem. 2007, 282, 34828-34838. [CrossRef] [PubMed]

67. Ikemoto, N.; Yamamoto, T. Regulation of calcium release by interdomain interaction within ryanodine receptors. Front. Biosci. 2002, 7, d671-d683. [CrossRef]

68. Fernandez-Velasco, M.; Gomez, A.M.; Richard, S. Unzipping RyR2 in adult cardiomyocytes: Getting closer to mechanisms of inherited ventricular arrhythmias? Cardiovasc. Res. 2006, 70, 407-409. [CrossRef]

69. Liu, N.; Rizzi, N.; Boveri, L.; Priori, S.G. Ryanodine receptor and calsequestrin in arrhythmogenesis: What we have learnt from genetic diseases and transgenic mice. J. Mol. Cell. Cardiol. 2009, 46, 149-159. [CrossRef]

70. Uchinoumi, H.; Yano, M.; Suetomi, T.; Ono, M.; Xu, X.; Tateishi, H.; Oda, T.; Okuda, S.; Doi, M.; Kobayashi, S.; et al. Catecholaminergic polymorphic ventricular tachycardia is caused by mutation-linked defective conformational regulation of the ryanodine receptor. Circ. Res. 2010, 106, 1413-1424. [CrossRef] [PubMed]

71. Xiong, J.; Liu, X.; Gong, Y.; Zhang, P.; Qiang, S.; Zhao, Q.; Guo, R.; Qian, Y.; Wang, L.; Zhu, L.; et al. Pathogenic mechanism of a catecholaminergic polymorphic ventricular tachycardia causing-mutation in cardiac calcium release channel RyR2. J. Mol. Cell. Cardiol. 2018, 117, 26-35. [CrossRef] [PubMed]

72. Kim, E.; Youn, B.; Kemper, L.; Campbell, C.; Milting, H.; Varsanyi, M.; Kang, C. Characterization of human cardiac calsequestrin and its deleterious mutants. J. Mol. Biol. 2007, 373, 1047-1057. [CrossRef]

73. Valle, G.; Arad, M.; Volpe, P. Molecular adaptation to calsequestrin 2 (CASQ2) point mutations leading to catecholaminergic polymorphic ventricular tachycardia (CPVT): Comparative analysis of R33Q and D307H mutants. J. Muscle Res. Cell Motil. 2020, 41, 251-258. [CrossRef]

74. Jalloul, Y.; Refaat, M.M. Novel variants in TECRL cause catecholaminergic polymorphic ventricular tachycardia. J. Cardiovasc. Electrophysiol. 2020, 31, 1536-1538. [CrossRef] [PubMed]

75. Sumitomo, N.; Sakurada, H.; Taniguchi, K.; Matsumura, M.; Abe, O.; Miyashita, M.; Kanamaru, H.; Karasawa, K.; Ayusawa, M.; Fukamizu, S.; et al. Association of atrial arrhythmia and sinus node dysfunction in patients with catecholaminergic polymorphic ventricular tachycardia. Circ. J. 2007, 71, 1606-1609. [CrossRef]

76. Kawamura, M.; Ohno, S.; Naiki, N.; Nagaoka, I.; Dochi, K.; Wang, Q.; Hasegawa, K.; Kimura, H.; Miyamoto, A.; Mizusawa, Y.; et al. Genetic Background of Catecholaminergic Polymorphic Ventricular Tachycardia in Japan. Circ. J. 2020, 84, 2124-2126. [CrossRef] [PubMed]

77. Ohno, S.; Hasegawa, K.; Horie, M. Gender Differences in the Inheritance Mode of RYR2 Mutations in Catecholaminergic Polymorphic Ventricular Tachycardia Patients. PLoS ONE 2015, 10, e0131517. [CrossRef]

78. Jiang, H.; Li, X.-M.; Ge, H.-Y.; Zhang, Y.; Liu, H.-J.; Li, M.-T. Investigation of Catecholaminergic Polymorphic Ventricular Tachycardia Children in China: Clinical Characteristics, Delay to Diagnosis, and Misdiagnosis. Chin. Med. J. 2018, 131, 2864-2865. [CrossRef]

79. Li, Q.; Guo, R.; Gao, L.; Cui, L.; Zhao, Z.; Yu, X.; Yuan, Y.; Xu, X. CASQ2 variants in Chinese children with catecholaminergic polymorphic ventricular tachycardia. Mol. Genet. Genomic. Med. 2019, 7, e949. [CrossRef]

80. Tester, D.J.; Dura, M.; Carturan, E.; Reiken, S.; Wronska, A.; Marks, A.R.; Ackerman, M.J. A mechanism for sudden infant death syndrome (SIDS): Stress-induced leak via ryanodine receptors. Heart Rhythm 2007, 4, 733-739. [CrossRef]

81. Rutter, N.; Southall, D.P. Cardiac arrhythmias misdiagnosed as epilepsy. Arch. Dis. Child. 1985, 60, 54-56. [CrossRef]

82. Yap, S.M.; Smyth, S. Ryanodine receptor 2 (RYR2) mutation: A potentially novel neurocardiac calcium channelopathy manifesting as primary generalised epilepsy. Seizure 2019, 67, 11-14. [CrossRef] [PubMed]

83. Lehnart, S.E.; Mongillo, M.; Bellinger, A.; Lindegger, N.; Chen, B.-X.; Hsueh, W.; Reiken, S.; Wronska, A.; Drew, L.J.; Ward, C.W.; et al. Leaky Ca2+ release channel/ryanodine receptor 2 causes seizures and sudden cardiac death in mice. J. Clin. Invest. 2008, 118, 2230-2245. [CrossRef] [PubMed]

84. Ozawa, J.; Ohno, S.; Fujii, Y.; Makiyama, T.; Suzuki, H.; Saitoh, A.; Horie, M. Differential Diagnosis Between Catecholaminergic Polymorphic Ventricular Tachycardia and Long QT Syndrome Type 1-Modified Schwartz Score. Circ. J. 2018, 82, 2269-2276. [CrossRef] 
85. Letsas, K.P.; Prappa, E.; Bazoukis, G.; Lioni, L.; Pantou, M.P.; Gourzi, P.; Degiannis, D.; Sideris, A. A novel variant of RyR2 gene in a family misdiagnosed as congenital long QT syndrome: The importance of genetic testing. J. Electrocardiol. 2020, 60, 8-11. [CrossRef] [PubMed]

86. Giudicessi, J.R.; Ackerman, M.J. Exercise testing oversights underlie missed and delayed diagnosis of catecholaminergic polymorphic ventricular tachycardia in young sudden cardiac arrest survivors. Heart Rhythm 2019, 16, 1232-1239. [CrossRef] [PubMed]

87. Wilde, A.A. Andersen-Tawil syndrome, scarier for the doctor than for the patient? Who, when, and how to treat. Europace 2013, 15, 1690-1692. [CrossRef]

88. Pflaumer, A.; Davis, A. Guidelines for the diagnosis and management of Catecholaminergic Polymorphic Ventricular Tachycardia. Heart Lung. Circ. 2012, 21, 96-100. [CrossRef]

89. Sy, R.W.; Krahn, A.D. Exercise testing: The catecholaminergic polymorphic ventricular tachycardia crystal ball? Europace 2012, 14, 1225-1227. [CrossRef]

90. Roston, T.M.; Kallas, D.; Davies, B.; Franciosi, S.; De Souza, A.M.; Laksman, Z.W.; Sanatani, S.; Krahn, A.D. Burst Exercise Testing Can Unmask Arrhythmias in Patients With Incompletely Penetrant Catecholaminergic Polymorphic Ventricular Tachycardia. JACC Clin. Electrophysiol. 2021, 7, 437-441. [CrossRef]

91. Van der Werf, C.; Wilde, A.A. Catecholaminergic polymorphic ventricular tachycardia: From bench to bedside. Heart 2013, 99, 497-504. [CrossRef]

92. Marjamaa, A.; Hiippala, A.; Arrhenius, B.; Lahtinen, A.M.; Kontula, K.; Toivonen, L.; Happonen, J.; Swan, H.; Tuiskula, A. Intravenous epinephrine infusion test in diagnosis of catecholaminergic polymorphic ventricular tachycardia. J. Cardiovasc. Electrophysiol. 2012, 23, 194-199. [CrossRef]

93. Watanabe, H.; Knollmann, B. Mechanism underlying catecholaminergic polymorphic ventricular tachycardia and approaches to therapy. J. Electrocardiol. 2011, 44, 650-655. [CrossRef]

94. Jabbari, J.; Jabbari, R.; Nielsen, M.W.; Holst, A.G.; Nielsen, J.B.; Haunsø, S.; Tfelt-Hansen, J.; Svendsen, J.H.; Olesen, M.S. New exome data question the pathogenicity of genetic variants previously associated with catecholaminergic polymorphic ventricular tachycardia. Circ. Cardiovasc. Genet. 2013, 6, 481-489. [CrossRef]

95. Giudicessi, J.R.; Lieve, K.V.; Rohatgi, R.K.; Koca, F.; Tester, D.J.; van der Werf, C.; Bos, J.M.; Wilde, A.A.; Ackerman, M.J. Assessment and Validation of a Phenotype-Enhanced Variant Classification Framework to Promote or Demote RYR2 Missense Variants of Uncertain Significance. Circ. Genom. Precis. Med. 2019, 12, e002510. [CrossRef]

96. Ackerman, M.J.; Priori, S.G.; Willems, S.; Berul, C.; Brugada, R.; Calkins, H.; Camm, A.J.; Ellinor, P.; Gollob, M.; Hamilton, R.; et al. HRS/EHRA expert consensus statement on the state of genetic testing for the channelopathies and cardiomyopathies this document was developed as a partnership between the Heart Rhythm Society (HRS) and the European Heart Rhythm Association (EHRA). Heart Rhythm 2011, 8, 1308-1339. [CrossRef] [PubMed]

97. Van der Werf, C.; Zwinderman, A.H.; Wilde, A.A. Therapeutic approach for patients with catecholaminergic polymorphic ventricular tachycardia: State of the art and future developments. Europace 2012, 14, 175-183. [CrossRef] [PubMed]

98. Leren, I.S.; Saberniak, J.; Majid, E.; Haland, T.F.; Edvardsen, T.; Haugaa, K.H. Nadolol decreases the incidence and severity of ventricular arrhythmias during exercise stress testing compared with $\beta 1$-selective $\beta$-blockers in patients with catecholaminergic polymorphic ventricular tachycardia. Heart Rhythm 2016, 13, 433-440. [CrossRef] [PubMed]

99. Padfield, G.J.; AlAhmari, L.; Lieve, K.V.; AlAhmari, T.; Roston, T.M.; Wilde, A.A.; Krahn, A.D.; Sanatani, S. Flecainide monotherapy is an option for selected patients with catecholaminergic polymorphic ventricular tachycardia intolerant of $\beta$-blockade. Heart Rhythm 2016, 13, 609-613. [CrossRef] [PubMed]

100. Bannister, M.L.; Thomas, N.L.; Sikkel, M.B.; Mukherjee, S.; Maxwell, C.; MacLeod, K.T.; George, C.H.; Williams, A.J The mechanism of flecainide action in CPVT does not involve a direct effect on RyR2. Circ. Res. 2015, 116, 1324-1335. [CrossRef] [PubMed]

101. Baltogiannis, G.G.; Lysitsas, D.N.; Di Giovanni, G.; Ciconte, G.; Sieira, J.; Conte, G.; Kolettis, T.M.; Chierchia, G.-B.; De Asmundis, C.; Brugada, P. CPVT: Arrhythmogenesis, Therapeutic Management, and Future Perspectives. A Brief Review of the Literature Front. Cardiovasc. Med. 2019, 6, 92. [CrossRef]

102. Schwartz, P.J. Cardiac sympathetic denervation to prevent life-threatening arrhythmias. Nat. Rev. Cardiol. 2014, 11, 346-353. [CrossRef]

103. Priori, S.G.; Blomström-Lundqvist, C.; Mazzanti, A.; Blom, N.; Borggrefe, M.; Camm, J.; Elliott, P.M.; Fitzsimons, D.; Hatala, R.; Hindricks, G. 2015 ESC Guidelines for the management of patients with ventricular arrhythmias and the prevention of sudden cardiac death: The Task Force for the Management of Patients with Ventricular Arrhythmias and the Prevention of Sudden Cardiac Death of the European Society of Cardiology (ESC). Endorsed by: Association for European Paediatric and Congenital Cardiology (AEPC). Eur. Heart J. 2015, 36, 2793-2867. [CrossRef] 
104. Al-Khatib, S.M.; Stevenson, W.G.; Ackerman, M.J.; Bryant, W.J.; Callans, D.J.; Curtis, A.B.; Deal, B.J.; Dickfeld, T.; Field, M.E.; Fonarow, G.C.; et al. 2017 AHA/ACC/HRS Guideline for Management of Patients with Ventricular Arrhythmias and the Prevention of Sudden Cardiac Death: A Report of the American College of Cardiology/American Heart Association Task Force on Clinical Practice Guidelines and the Heart Rhythm Society. J. Am. Coll. Cardiol. 2018, 72, e91-e220. [CrossRef]

105. Pizzale, S.; Gollob, M.; Gow, R.; Birnie, D.H. Sudden death in a young man with catecholaminergic polymorphic ventricular tachycardia and paroxysmal atrial fibrillation. J. Cardiovasc. Electrophysiol. 2008, 19, 1319-1321. [CrossRef]

106. Mohamed, U.; Gollob, M.; Gow, R.M.; Krahn, A.D. Sudden cardiac death despite an implantable cardioverter-defibrillator in a young female with catecholaminergic ventricular tachycardia. Heart Rhythm 2006, 3, 1486-1489. [CrossRef]

107. Marai, I.; Khoury, A.; Suleiman, M.; Gepstein, L.; Blich, M.; Lorber, A.; Boulos, M. Importance of ventricular tachycardia storms not terminated by implantable cardioverter defibrillators shocks in patients with CASQ2 associated catecholaminergic polymorphic ventricular tachycardia. Am. J. Cardiol. 2012, 110, 72-76. [CrossRef] [PubMed]

108. Roses-Noguer, F.; Jarman, J.W.; Clague, J.R.; Till, J. Outcomes of defibrillator therapy in catecholaminergic polymorphic ventricular tachycardia. Heart Rhythm 2014, 11, 58-66. [CrossRef] [PubMed]

109. Roston, T.M.; Jones, K.; Hawkins, N.M.; Bos, J.M.; Schwartz, P.J.; Perry, F.; Ackerman, M.J.; Laksman, Z.W.; Kaul, P.; Lieve, K.V.; et al. Implantable cardioverter-defibrillator use in catecholaminergic polymorphic ventricular tachycardia: A systematic review. Heart Rhythm 2018, 15, 1791-1799. [CrossRef] [PubMed]

110. Miyake, C.Y.; Webster, G.; Czosek, R.J.; Kantoch, M.J.; Dubin, A.M.; Avasarala, K.; Atallah, J. Efficacy of implantable cardioverter defibrillators in young patients with catecholaminergic polymorphic ventricular tachycardia: Success depends on substrate. Circ. Arrhythm. Electrophysiol. 2013, 6, 579-587. [CrossRef] [PubMed]

111. Ostby, S.A.; Bos, J.M.; Owen, H.J.; Wackel, P.L.; Cannon, B.C.; Ackerman, M.J. Competitive Sports Participation in Patients With Catecholaminergic Polymorphic Ventricular Tachycardia: A Single Center's Early Experience. JACC Clin. Electrophysiol. 2016, 2, 253-262. [CrossRef]

112. Kobayashi, S.; Yano, M.; Uchinoumi, H.; Suetomi, T.; Susa, T.; Ono, M.; Xu, X.; Tateishi, H.; Oda, T.; Okuda, S.; et al. Dantrolene, a therapeutic agent for malignant hyperthermia, inhibits catecholaminergic polymorphic ventricular tachycardia in a RyR2(R2474S/+) knock-in mouse model. Circ. J. 2010, 74, 2579-2584. [CrossRef] [PubMed]

113. Kobayashi, S.; Bannister, M.; Gangopadhyay, J.P.; Hamada, T.; Parness, J.; Ikemoto, N. Dantrolene stabilizes domain interactions within the ryanodine receptor. J. Biol. Chem. 2005, 280, 6580-6587. [CrossRef] [PubMed]

114. Suetomi, T.; Yano, M.; Uchinoumi, H.; Fukuda, M.; Hino, A.; Ono, M.; Xu, X.; Tateishi, H.; Okuda, S.; Doi, M.; et al. Mutationlinked defective interdomain interactions within ryanodine receptor cause aberrant $\mathrm{Ca}^{2+}$ release leading to catecholaminergic polymorphic ventricular tachycardia. Circulation 2011, 124, 682-694. [CrossRef]

115. Penttinen, K.; Swan, H.; Vanninen, S.; Paavola, J.; Lahtinen, A.M.; Kontula, K.; Aalto-Setälä, K. Antiarrhythmic Effects of Dantrolene in Patients with Catecholaminergic Polymorphic Ventricular Tachycardia and Replication of the Responses Using iPSC Models. PLoS ONE 2015, 10, e0125366.

116. Laksman, Z.; Barichello, S.; Roston, T.M.; Deyell, M.W.; Krahn, A.D. Acute Management of Ventricular Arrhythmia in Patients With Suspected Inherited Heart Rhythm Disorders. JACC Clin. Electrophysiol. 2019, 5, 267-283. [CrossRef]

117. De Rosa, G.; Delogu, A.B.; Piastra, M.; Chiaretti, A.; Bloise, R.; Priori, S.G. Catecholaminergic polymorphic ventricular tachycardia: Successful emergency treatment with intravenous propranolol. Pediatr. Emerg. Care. 2004, 20, 175-177. [CrossRef]

118. Bezzerides, V.J.; Caballero, A.; Wang, S.; Ai, Y.; Hylind, R.J.; Lu, F.; Heims-Waldron, D.A.; Chambers, K.D.; Zhang, D.; Abrams, D.; et al. Gene Therapy for Catecholaminergic Polymorphic Ventricular Tachycardia by Inhibition of Ca. Circulation 2019, 140, 405-419. [CrossRef]

119. Zhang, X.-H.; Wei, H.; Xia, Y.; Morad, M. Calcium signaling consequences of RyR2 mutations associated with CPVT1 introduced via CRISPR/Cas9 gene editing in human-induced pluripotent stem cell-derived cardiomyocytes: Comparison of RyR2-R420Q, F2483I, and Q4201R. Heart Rhythm 2021, 18, 250-260. [CrossRef]

120. Meraviglia, V.; Arendzen, C.H.; Freund, C.; Atsma, D.E.; Mummery, C.L.; Bellin, M. Generation of two human induced pluripotent stem cell lines, LUMCi020-A and LUMCi021-A, from two patients with Catecholaminergic Polymorphic Ventricular Tachycardia carrying heterozygous mutations in the RYR2 gene. Stem. Cell Res. 2020, 45, 101764. [CrossRef] [PubMed] 